\title{
Allan Sekula en Galicia: dos series fotográficas sobre trabajo, capitalismo y crisis
}

\section{Allan Sekula in Galicia: two photograpy series on work, capitalism and crisis}

\author{
Miguel Anxo Rodríguez González \\ Universidad de Santiago de Compostela
}

Fecha de recepción: 2 de enero de 2020

Fecha de aceptación: 10 de julio de 2020

\section{RESUMEN}

Allan Sekula, uno de los principales referentes de la fotografía documental, realizó dos series en Galicia: Mensaxe nunha botella (1992) y Black Tide/Marea negra (2002-2003), resultado de dos encargos, el primero de la Fotobienal de Vigo y el segundo del periódico La Vanguardia. El fotógrafo centró su atención en trabajos y personas relacionados con el mar, desde estibadores hasta voluntarios y marineros involucrados en la limpieza de la costa tras el accidente del petrolero Prestige. Esta investigación se propone analizar las series, explicar las circunstancias de su realización y responder a la pregunta de hasta qué punto, tratándose de encargos, el fotógrafo se mantuvo fiel a su programa para la "nueva fotografía documental", establecido en los primeros años de su trayectoria.

\section{PALABRAS CLAVE}

Fotografía documental. Allan Sekula. Galicia. Trabajo. Crisis. Prestige.
Anuario del Departamento de Historia y Teoría del Arte

vol. 32, 2020, pp. 137-159

ISSN: 1130-5517, eISSN: 2530-3562

https://doi.org/10.15366/anuario2020.32.007

\begin{abstract}
Allan Sekula, one of the main referents in documentary photography, carried out two series in Galicia: Mensaxe nunha botella (1992) and Black Tide/Marea negra (2002-2003), as a result of commissions from the Fotobienal de Vigo and from a newspaper, La Vanguardia. He focused on works and people related to the sea, from dock workers to volunteers and sailors involved in the cleaning of the coast after the accident of the oil tanker Prestige. This investigation aims at analysing the photoworks, explaining the circumstances of their production and answering the question of how far, in the case of commissions, the photographer remained faithful to his programme for a "new documentary photography", established in the early years of his career.
\end{abstract}

\section{KEY WORDS}

Documentary photography. Allan Sekula. Galicia. Work. Crisis. Prestige. 
Allan Sekula (Erie, Pensilvania 1951- Los Ángeles 2013) es uno de los principales representantes de la "nueva fotografía documental", que plantea una revisión crítica de los postulados de la fotografía de vanguardia a la vez que un distanciamiento de la fotografía documental "humanista" de los grandes maestros ${ }^{1}$ Desde la introducción de su primer foto-libro, Photography Against the Grain (1984), Sekula mostró sus preferencias por un tipo de fotografía con referente social, frente a la usual autorreferencialidad del arte de vanguardia $^{2}$. A la vez, renunció a la selección del momento culminante de la acción, combinando situaciones y personajes variados, así como diferentes puntos de vista, con lo que evitó los excesos dramáticos característicos de la fotografía documental.

Algunos de los males que aquejaban a la fotografía vendrían dados -en la lectura de Sekula- por el esteticismo que había alcanzado a la fotografía de tipo documental y provocado la búsqueda de una interpretación en clave emotiva y espiritual de los acontecimientos ${ }^{3}$. De este modo, los fotógrafos documentalistas habrían renunciado al valor de verdad en aras de su interés por el reconocimiento artístico de su profesión: "la concepción de la fotografía como arte superior sólo fue posible a través de su transformación en un fetiche abstracto, una "forma transcendente""4.

Allan Sekula realizó dos series en Galicia, la primera en octubre de 1992 y la segunda en diciembre de 2002. Son trabajos que responden a los encargos de la V Fotobienal de Vigo y del periódico La Vanguardia, respectivamente. Aunque el carácter de cada serie es totalmente distinto, de modo coherente con la investigación que estaba llevando a cabo durante estos años, Sekula se centró en ambos casos en trabajos y actividades relacionadas con el mar. El estudio de situaciones concretas, a escala local, planteaba cuestiones de más amplio alcance pues conectaba con las transformaciones y crisis del capitalismo global. En Mensaxe nunha botella, serie que realizó para la Fotobienal de Vigo de 1992, Sekula documentó trabajos relacionados con el mar y otros aspectos de la realidad social, como el cierre de negocios o los recortes en los subsidios al paro. En el segundo caso, Black Tide/Marea negra (2002-2003), la crisis que registró con su cámara era de tipo ecológico, provocada por los vertidos de fuel del petrolero Prestige. El desastre del Prestige afectó a la costa gallega y desencadenó una movilización social sin precedentes que, por un lado, implicó auto-organización para las tareas de limpieza de la costa y, por otro, dio lugar a fuertes protestas contra la gestión política de la catástrofe ${ }^{5}$. Esta segunda serie puede ser vista también como un precedente en el trabajo de representación y denuncia del capitalismo extractivista, frecuente en las artes plásticas en los últimos años.

En ambos casos, el trabajo humano se ubicaba en un contexto de crisis, o apuntaba a una situación de colapso del sistema. Las fotografias dejaban traslucir la dureza de un contexto y un tipo de trabajo que parecía ser negado por la nueva imagen del capitalismo, que se pretende "desmaterializado" y se identifica con los procesos de gestión inteligentes y las nuevas tecnologías. La dureza del trabajo sigue ahí, nos parece indicar Sekula en sus series, y el ámbito marítimo se mostraba como un espacio de interacciones y flujos paradójicamente intenso: es en el mar donde se producen la mayor parte de los desplazamientos de mercancías a gran escala, necesarios para que el sistema se mantenga. Pero también es el mar el espacio donde las desigualdades se imponen con rotundidad (fig. 1).

\footnotetext{
${ }^{1}$ Quisiera agradecer a Carles Guerra, Manuel y Olaia Sendón, Pedro de Llano y Carla Giachello la ayuda prestada para la realización de este artículo.

2 Allan SEKULA, "Introduction", en Photography against the Grain. Essays and Photo Works. 1973-1983, Mack, 2016 [Nova Scotia College of Art and Design, 1984].

3 Allan Sekula, "Sobre a invención do significado da fotografía", Grial. Revista Galega de Cultura, 139 (julio - septiembre de 1998), pp. 466-468.

4 Ibidem, p. 470. Traducción del autor.

${ }^{5}$ En este artículo se mantendrá el título original de la serie, Mensaxe nunha botella, en gallego, al ser positivada y presentada por primera vez en público de este modo, en el marco de la Fotobienal de Vigo. En el caso de la serie sobre la marea negra, se diferenciará el título en castellano de la pieza publicada en La Vanguardia ("Marea negra: fragmentos para una ópera"), que contenía además el texto del propio fotógrafo, de la serie positivada y comercializada poco después por su galería californiana: Black Tide/Marea negra.
} 


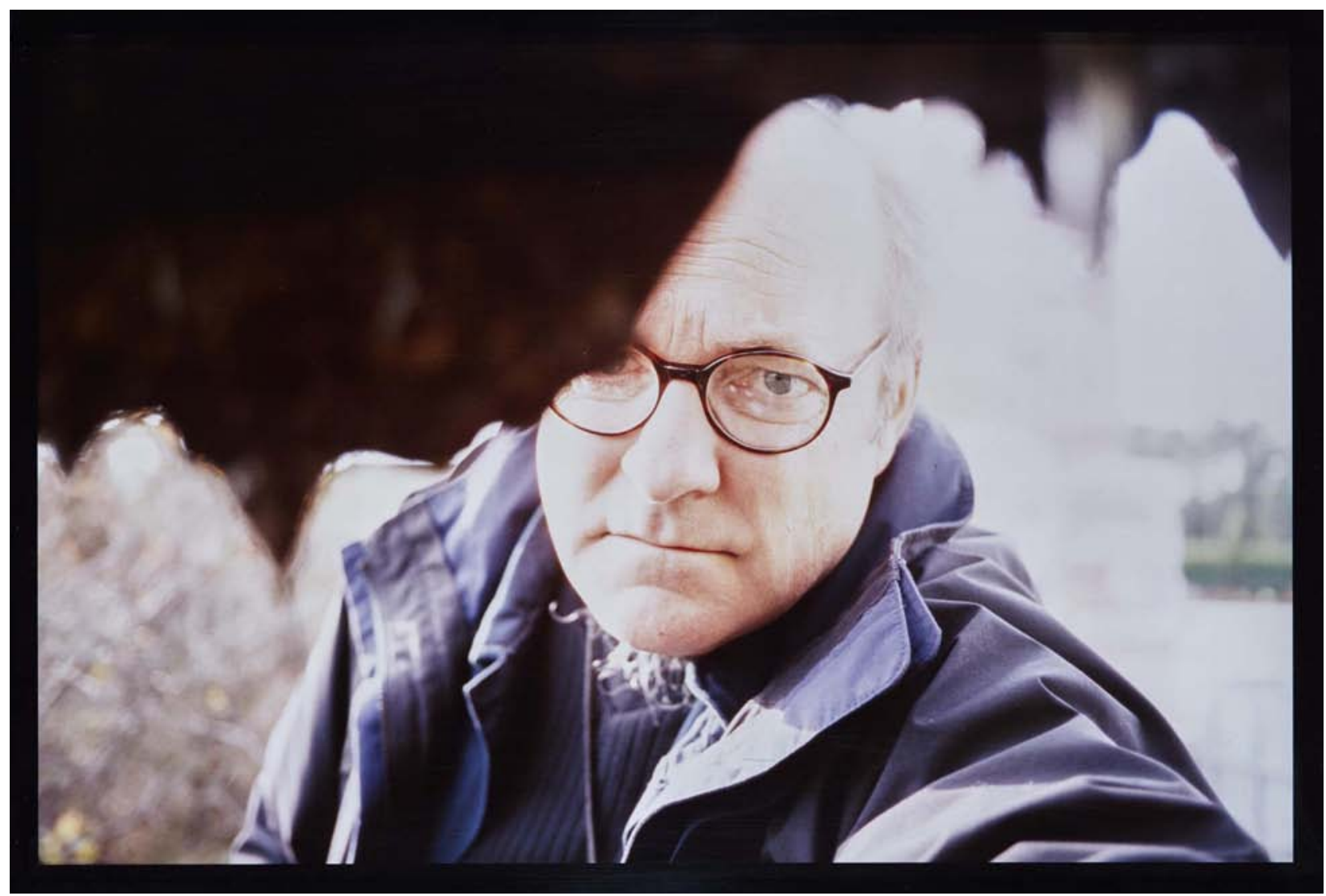

Fig. 1. Allan Sekula, Autorretrato (Lendo, 12-22-02), de la serie Black Tide/Marea Negra, 2002-2003, cibachrome sobre poliéster, con marco: 37,3 x 52,2 cm, Colección MNCARS, Madrid.

En los últimos trabajos de Sekula entran elementos de tipo narrativo y simbólico que llegan a determinar el sentido de las series y, a la vez, pueden complicar la interpretación de su obra. Me refiero aquí a la introducción de figuras de la mitología clásica como Sísifo, presente en la serie realizada en Galicia sobre el Prestige, o Hércules, en el proyecto realizado para la Documenta de Kassel de 2007. Black Tide/Marea negra se presentó como un trabajo transdisciplinar, con una combinación peculiar de fotografía y ópera, con la figura de Sísifo como eje simbólico. Alude al trabajo que nunca acaba, persistente y absurdo, de los voluntarios que retiran chapapote con marea baja, para volver a ver la costa manchada tras la marea alta. ¿Se mantiene en estas series el impulso dialéctico de su propuesta de una fotografía documental crítica de las décadas de los setenta y ochenta? ¿Hasta qué punto la introducción de elementos de tipo simbólico abre una perspectiva nueva en la fase final de su trabajo? ¿Se llega a imponer un cierto sentido épico al final de su trayectoria, en las series relacionadas con el activismo anti-capitalista y la movilización social?

\section{Sekula, Rosler, Lonidier}

Entre los años sesenta y setenta, Allan Sekula llevó a cabo, junto con Martha Rosler y Fred Lonidier, un intenso trabajo de cuestionamiento de los preceptos de la fotografía contemporánea. Compañeros de estudios en la Escuela de Arte de la Universidad de California, en San Diego, se embarcaron en un trabajo de desmontaje que derivó en series fotográficas como The Bowery in two inadequate descriptive systems de Martha Rosler (1975), The health and safety game de Fred Lonidier (1976), o School is a factory 
del propio Sekula (1978-80). ${ }^{6}$ Quisieron marcar distancias tanto con la fotografía artística de vanguardia como con la documental. Una combinación de marxismo, lingüística y arte experimental dio como resultado la concreción de una estética característica, asociada al llamado "grupo de San Diego".

En este programa de desmontaje, o "desmantelamiento" - para usar el término que prefería Sekula-, del modelo instaurado de fotografía documental, el cine experimental francés habría de servir de ayuda, al hacer visibles las condiciones de producción y la "factura" artificial del producto fílmico. Aunque se tratara de otra modalidad artística, el propósito de estos fotógrafos pasaba por asumir el carácter narrativo y comunicacional del medio y, por este motivo, se acercaron a los cineastas experimentales, como Jean-Luc Godard o Chris Marker, que podían ofrecer otras formas de ensamblaje de imágenes, modalidades discursivas donde se explota la potencia expresiva de las secuencias, los desajustes y colisiones entre estas, y entre estas y el sonido ${ }^{7}$. El propio Sekula reconocía -ya en los últimos años de vida- su fascinación por llevar a la cámara al extremo de sus posibilidades, incluso cuando esto implicaba "tener que limpiar regularmente de sal la lente", en proyectos relacionados con el medio marítimo ${ }^{8}$.

Otro elemento que influenció al trío Sekula, Rosler, Lonidier fue el trabajo sobre el lenguaje. Este vendría dado especialmente por la actividad docente del poeta y crítico David Antin, con su insistencia en los estudios de lingüística, que los fotógrafos admitirían como fundamentales, pero también por la irrupción de las nuevas tendencias y el arte conceptual. Conocían el trabajo de algunos de los artistas del incipiente conceptual norteamericano de finales de los sesenta y primeros setenta que también mezclaban imagen y texto (John Baldessari, Douglas Huebler, incluso Art \& Language) aunque, según Martha Rosler, no se sintieron nunca demasiado interesados por ellos por su falta de implicación política. Otro de los elementos que distingue al grupo californiano de los conceptuales aquí citados es la preferencia por lo narrativo, una peculiar utilización del lenguaje que oscila entre el estilo neutro y una narrativa más cercana a lo literario o lo cinematográfico.

El resultado final, en las series de Sekula, es una narrativa visual poco clara, incluso de apariencia ilegible. Para Benjamin Buchloh, esta dificultad se ve incrementada por su predilección por un tema como es el del trabajo (las condiciones materiales del trabajo en la sociedad capitalista), aparentemente marginal en el ámbito del arte contemporáneo en esas décadas 9. Martha Rosler defiende la existencia de una conciencia crítica que funcionaría como motor del grupo de San Diego, de modo que asumieron como su misión el llevar a cabo un desafío en toda regla a los preceptos de la práctica fotográfica:

En nuestro propio grupúsculo analizábamos textos teóricos y políticos, y los acontecimientos que tenían lugar, pero también estábamos pendientes del "mundo del arte" de la costa este y de Europa, en particular del arte conceptual. (...) Estábamos decididos a cambiar el mundo del arte, sobre todo la práctica y la interpretación de la fotografía. Pero lo más importante es que queríamos desarrollar una práctica dual, que actuara dentro y fuera de las instituciones (...). Animados por Fred, sobre todo, considerábamos que nuestra estrategia tenía tres vertientes: nuestra misión era crear obras, practicar la enseñanza y escribir. La tarea de escribir textos que explicaran nuestra posición recayó sobre Allan Sekula y sobre mín ${ }^{10}$.

6 Ver 'Luchas documentales en los 'largos setenta'. Conversaciones con Rosa Casanova, Duncan Forbes, Patricia Hayes, Sarah James, Fred Lonidier, Silvia Pérez Fernández, Martha Rosler, Rolf Sachsse y Siona Wilson, moderadas por Jorge Ribalta”, en J. Ribalta (ed.), Aún no. Sobre la reinvención del documental y la crítica de la modernidad. Ensayos y documentos (19721991), Madrid, MNCARS, 2015, pp. 78-90.

7 Ibidem, p. 81.

8 Hilde van GELDER, "The shape of the pictorial in contemporary photography", Image [\&] Narrative, 1, Vol. X (2009), pp. 204-230. [en línea], http://www.imageandnarrative.be/index.php/imagenarrative/article/view/212/176 [Consulta: 22 de octubre de 2020].

9 Buchloh se refiere a la "imposibilidad contemporánea de una iconografía del trabajo en la autodenominada sociedad postindustrial. Benjamin H. D. BuchloH, “Allan Sekula: between discourse and document”, en A. Sekula y C. Lorenz (eds.), Allan Sekula: Fish Story, Rotterdam, Düsseldorf, Witte de With \& Richter Verlag, 2002 [1ª edición, 1995], p.191.

10 Martha Rosler, citado en Ribalta (ed.), 2015, p. 80. 
Sekula comenzó a esbozar un tipo de práctica fotográfica que, partiendo de una investigación a fondo de situaciones, captaba secuencias o pequeñas historias a modo de aproximaciones al tema que luego habrían de ser presentadas con acompañamiento de texto. Imagen y palabra, en el programa de Sekula, establecen una relación que podría adoptar formas variadas, del refuerzo al solapamiento o a la distorsión crítica del significado. Siendo el significado de la imagen un aspecto siempre problemático, el fotógrafo reconoce una necesidad de complementariedad entre palabra e imagen y, en palabras de Susan Bright, "sitúa el lenguaje y el contexto en el núcleo de significado de la fotografía"11.

Benjamin Buchoh destacará en Sekula el trabajo de "reconstrucción de un realismo crítico" frente a los postulados del arte contemporáneo, que habían casi descartado esa opción ${ }^{12}$. Esta toma de posición supondrá un distanciamiento con respecto a las nociones de creatividad asociadas al estilo personal que venían afectando tanto a la vanguardia artística como al fotoperiodismo de los "grandes maestros". Era el estilo, precisamente lo que había que evitar, porque interponía al sujeto creador en la evaluación crítica de imágenes que documentan situaciones.

\section{La Fotobienal de Vigo, 1990 y 1992}

La primera visita del Allan Sekula a Galicia tuvo lugar en 1990, al ser invitado a mostrar una selección de su trabajo y dar una conferencia en Vigo, en el marco de la IV Fotobienal. Este evento estaba dirigido por Manuel Sendón y Xosé Luis Suárez Canal quienes poco antes habían puesto en marcha el Centro de Estudos Fotográficos, plataforma desde la que estaban planteando un trabajo de recuperación de maestros de la fotografía gallega y de puesta al día del medio fotográfico. La Fotobienal, organizada de modo independiente, consiguió en pocos años asentarse como uno de los acontecimientos fotográficos más interesantes del panorama peninsular, y pronto contó con el apoyo económico del Ayuntamiento de Vigo $^{13}$.

Sendón y Suárez Canal habían conocido el trabajo del fotógrafo californiano a través de publicaciones internacionales y contactaron directamente con él a partir de una búsqueda telefónica ${ }^{14}$. La lectura de textos de autores como Sekula y Rosler estaba ayudando a los organizadores de la Fotobienal a llevar a cabo una revisión en profundidad de la fotografía documental ${ }^{15}$. De este modo, en la edición de 1990 se pudo ver en Vigo la obra de Sekula, Martha Rosler, Karen Knorr, William Eaglestone y Nan Goldin -entre otros- dentro de la sección "Documentalismo social contemporáneo". Un texto de Michael Gibbs sobre la fotografía documental aportaba la base teórica y destacaba la desconfianza de Rosler y Sekula ante la presunta transparencia del medio a la hora de transmitir significados y reflejar la realidad ${ }^{16}$. Gibbs remitía al trabajo de investigación sobre el contexto que llevaban a cabo estos fotógrafos y vinculaba las estrate-

\footnotetext{
11 Susan Bright, Fotografía hoy, San Sebastián, Nerea, 2005, p.186.

12 “...Sekula's Project is engaged in the reconstruction of critical realism after and against the abrogation of photography by modernist aesthetics". BuCHLOH, 2002, p.192.

13 La Fotobienal se celebró entre 1984 y 2000. Para una información más detallada sobre la evolución y las distintas ediciones, ver Manuel SEndón, “A Fotobienal de Vigo e o Centro de Estudos Fotográficos”, Grial. Revista Galega de Cultura, vol. 56, no 220 (octubre-diciembre de 2018), pp. 124-131; Manuel SEndón, y Xosé Luis SuÁrez Canal, "O feito fotográfico. Vigo, 19842000", [en línea], https://cefvigo.wordpress.com/o-feito-fotografico-vigo-1984-2000/ [Consulta: 10 de julio de 2020].

14 Manuel Sendón, entrevista personal, en Vigo, 1 de marzo de 2018. Una vez tuvieron el contacto, lo llamaron y enviaron por correo postal una selección de catálogos producidos por la Fotobienal, que sirvieron de carta de presentación del evento.

15 Con respecto a esto último, el propio Sendón recuerda la mala acogida entre los fotoperiodistas de la ciudad de las primeras muestras de fotografía internacional en la Fotobienal. Manuel Sendón, entrevista personal, en Vigo, 1 de marzo de 2018.

16 Michael GibBS, "Discursos documentais", en IV Fotobienal. Vigo 1990, Manuel Sendón y Xosé Luis Suárez Canal (comis.), Vigo, Concello de Vigo / Centro de Estudos Fotográficos (catálogo de la exposición celebrada del 31 de octubre al 30 de noviembre de 1990), 1990, p. 68.
} 


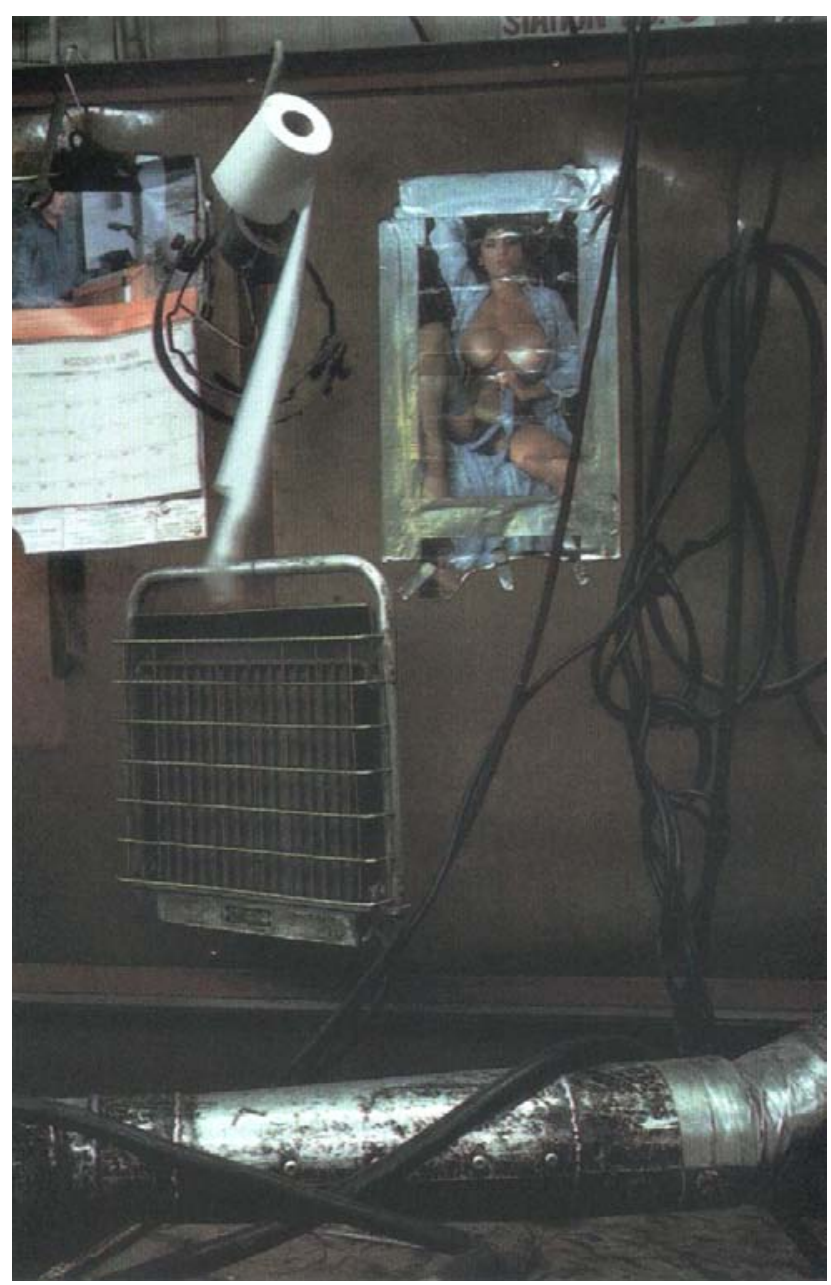

Fig. 2. Allan Sekula, Cabina de soldador en un astillero en bancarrota. Puerto de Los Ángeles, San Pedro, California, septiembre de 1989, fotografía, reproducida en el catálogo IV Fotobienal - Vigo 90, Centro de Estudos Fotográficos, Concello de Vigo, 1990, p.64. gias retóricas de Sekula con el teatro de Bertolt Brecht: "Sekula acepta el contexto de la galería o del museo para promulgar sus 'lecciones', del mismo modo que Brecht aceptaba el teatro para sus 'Lehrstücke'"17. La presencia de textos acompañando, en ocasiones incluidos dentro de las mismas fotografías, era uno de los elementos que los organizadores destacaban ya en las páginas introductorias, apuntando a la insuficiencia de la imagen, por sí sola, para la construcción del sentido.

El catálogo recoge cuatro fotografías de Sekula de objetos abandonados en instalaciones decrépitas, etiquetadas con el texto "Cabina de soldador en un astillero en bancarrota. Puerto de Los Ángeles, San Pedro, California, Septiembre, 1989" (fig. 2); y un texto en el que el autor alude a la transformación de este puerto, el mayor de EEUU en tráfico de mercancías, pero donde ya no se construyen barcos ${ }^{18}$. Las fotografías -que formarán parte del capítulo introductorio de Fish Story - tocaban directamente una realidad de desindustrialización que la ciudad de Vigo estaba sufriendo duramente en esos mismos años. Sekula reflexionaba en el texto sobre el "doble proceso de momificación" que el sistema capitalista lleva a cabo: primero la fuerza de trabajo, "embalsamada dentro del capital activo", luego la conservación estética del capital industrial obsoleto ${ }^{19}$. Pero al final -concluye Sekula-, el trabajo humano vuelve, como un zombi, resucita y se nos aparece, "a pesar de la fantasía burguesa de un mundo sin trabajadores" 20 .

Cuando Sekula acudió al certamen para presentar su obra, en 1990, llevó consigo una edición de su libro Photography against the Grain que Sendón y Suárez Canal fotocopiaron y pusieron en circulación entre algunos de sus contactos ${ }^{21}$. Para la edición siguiente los organizadores propondrán a Sekula realizar un trabajo en la ciudad en el marco de la sección "Vigovisións". Este es el origen del conjunto de fotografías que compondrá Mensaxe nunha botella, que será luego aprovechada por el artista para conformar el capítulo 5 de su foto-libro Fish Story (1995).

Mensaxe nunha botella fue realizada en octubre de 1992, en el marco de la V Fotobienal de Vigo. Esta edición estaba estructurada en varios apartados: una exposición dedicada a América Latina, otra con tra-

\footnotetext{
17 Idem.

18 Allan Sekula, "Conto do peixe", en Ibidem, pp. 63.

19 Idem.

20 Idem.

21 Manuel Sendón, entrevista personal, en Vigo, 1 de marzo de 2018.
} 
bajos de los beneficiarios de la beca de la Fotobienal, una antológica que recuperaba una figura histórica de la fotografía gallega - ese año, Luis Ksado- y "Vigovisións", que ofrecía trabajos realizados ex profeso en la ciudad por destacados fotógrafos ${ }^{22}$. Entre el 1 y el 10 de octubre de 1992, Sekula tomó con su cámara un conjunto de imágenes en varios espacios de la ciudad -el puerto, las calles, una playa cercana- y en alta mar, a bordo de un barco pesquero, de las que se seleccionaron ocho para la muestra ${ }^{23}$. La secuencia fotográfica final, compuesta por diez piezas, se completó con la lista de las imágenes (texto en blanco sobre fondo negro) y un texto en gallego en el que el fotógrafo establecía una reflexión en torno a la riqueza, el mar y la acumulación capitalista ${ }^{24}$. Sekula vinculaba aquí las riquezas del mar que supuestamente esconde el fondo de la Ría de Vigo (por el naufragio de la escuadra hispano-francesa en la Batalla de Rande, de 1702), con la figura del Capitán Nemo y la idea de "acumulación capitalista" formulada por Marx. Es un trabajo que combina elementos de una narrativa en torno a las riquezas del mar y la crisis económica, que apunta a la situación de la ciudad en el cambio de década. El título Mensaxe nunha botella remite a la fotografía de una carabela del escaparate de una joyería, pero también tiene implicaciones que remiten a la idea de desaparición, pérdida y mensaje de socorro lanzado al mar, a un destinatario desconocido (figs. 3 y 4 ).

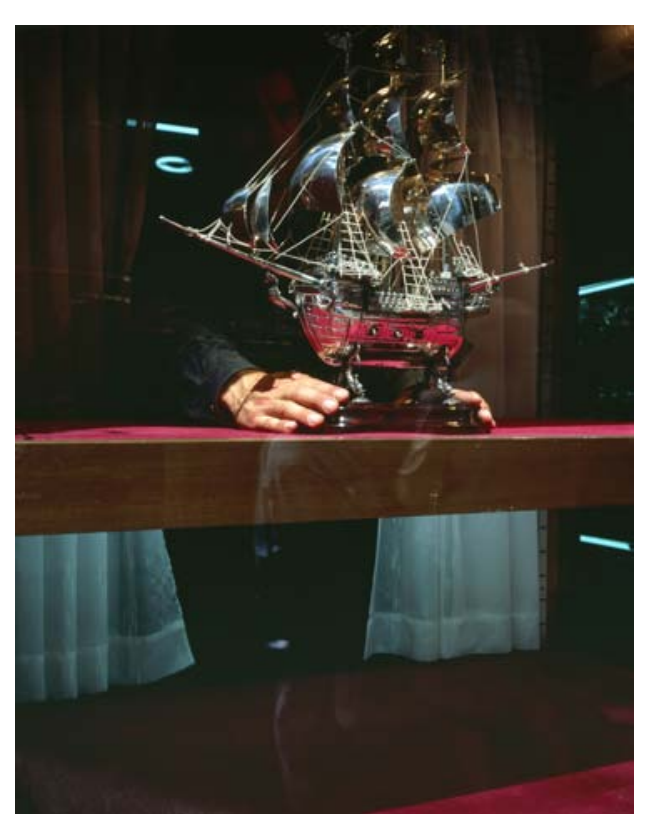

Fig. 3. Allan Sekula, Joyería. Rúa Príncipe, de la serie Mensaxe nunha botella, 1992, capítulo 5 de Fish Story (1989-95), ThyssenBornemisza Art Contemporary Collection.

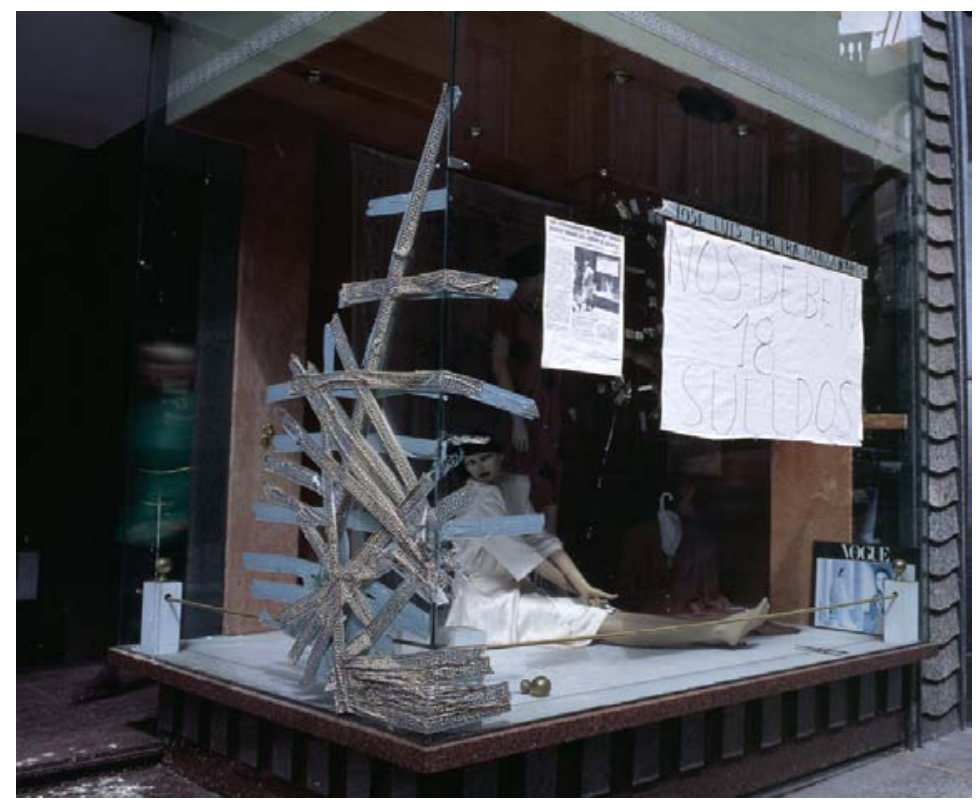

Fig. 4. Allan Sekula, Tienda ocupada durante 18 meses por dependientas en lucha por sus salarios. Rúa Príncipe, de la serie Mensaxe nunha botella, 1992, capítulo 5 de Fish Story, 1989-95, Thyssen-Bornemisza Art Contemporary Collection.

22 Graciela Iturbide, John Davis, Larry Flynt y Xulio Correa completaron el apartado "Vigovisións" de la publicación $V$ Fotobienal de Vigo 1992, Manuel Sendón y Xosé Luis Suárez Canal (comis.), Vigo, Concello de Vigo / Centro de Estudos Fotográficos (catálogo de la exposición celebrada del 29 de octubre al 29 de noviembre de 1992), 1992, pp. 9-34.

${ }^{23}$ Los organizadores acompañaban a los fotógrafos que participaban en esta sección, facilitaban el acceso a determinadas localizaciones, y colaboraban en la producción de las fotografías. Estas pasaban a formar un fondo fotográfico, hoy propiedad del Ayuntamiento de Vigo. Manuel Sendón, entrevista personal, en Vigo, 1 de marzo de 2018.

${ }^{24}$ Las fotografías se imprimieron en formatos vertical y horizontal, de 59,7 x 39,7 cm, y sus temas se dividen en: mujeres en la lonja (2), escaparates en el centro urbano (2), un marinero trabajando, un estibador, una hoguera y una imagen en la playa. La pieza con el texto sobre el capitán Nemo tiene un tamaño algo mayor: 101,5 x $71 \mathrm{~cm}$. 
La secuencia comienza con dos fotografías tomadas en el centro de la ciudad. La estrategia de contraposición de aspectos de una misma realidad -reconstrucción del contexto por oposición- viene establecida al situar juntas la fotografía de una maqueta de barco (una carabela), hecha con metales preciosos, en una joyería, y otra del escaparate de una tienda de moda con cristales rotos y un cartel que alude a luchas sindicales en un contexto de crisis: "NOS DEBEN 18 SUELDOS". Evidente es aquí el juego del autor, creando un cortocircuito por el contraste entre condiciones de trabajo, crisis y representación de bienes de consumo. Otro grupo apunta directamente a trabajos vinculados con la pesca, sector crucial en la economía viguesa: las imágenes de un estibador en el puerto, mujeres pesando pescado y un marinero trabajando de noche en la cubierta de un pesquero se ofrecen como registro de formas del trabajo con un

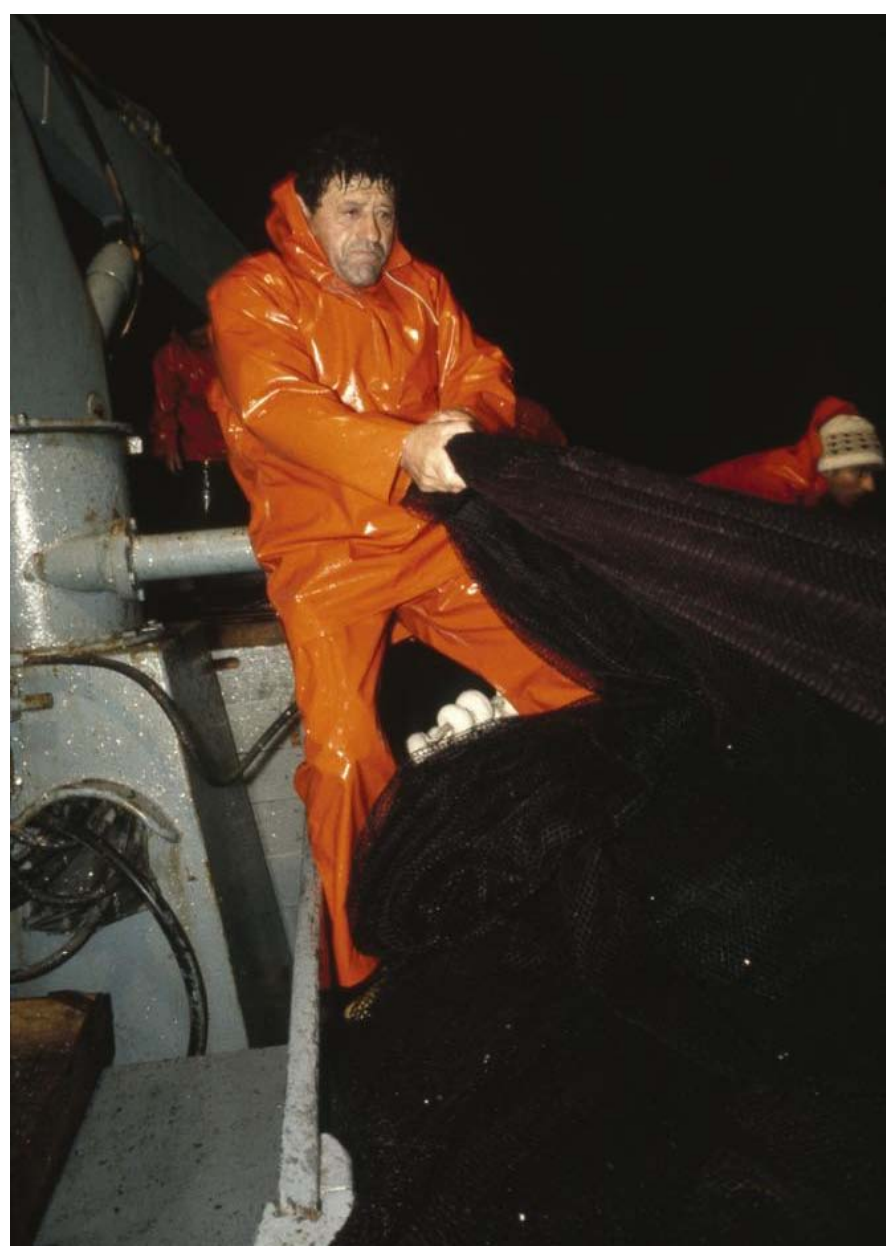

Fig. 5. Allan Sekula, Jornada sin éxito de pesca de sardinas frente a la costa portuguesa, de la serie Mensaxe nunha botella, 1992, capítulo 5 de Fish Story (1989-95), Thyssen-Bornemisza Art Contemporary Collection. fuerte componente físico, que parecen contradecir la imagen de una economía postindustrial ingrávida. Intuimos un desajuste con respecto al discurso celebrativo de los apóstoles de la economía postindustrial que recientemente Ben Lerner ha planteado en relación con una imagen tomada en el puerto, no incluida en "Vigovisións" pero sí en Fish Story, de un estibador dirigiendo las operaciones de descarga de pescado congelado que, a su vez, es controlado por las fuerzas ocultas del capital. ${ }^{25}$

En general, el registro de las acciones es sobrio, no busca la dramatización. De estas representaciones, sólo la del marinero en la cubierta del barco adquiere un cierto tono dramático por la postura en que se capta, que alude a la fuerza física y dureza del trabajo y por el contraste cromático entre el rojo del impermeable y el fondo negro. Sekula aludirá con una breve nota al contexto del registro: una jornada de pesca de sardinas que acabó sin éxito, cerca de la costa portuguesa ${ }^{26}$ (fig. 5).

La serie se completaba con una fotografía de una hoguera ardiendo por la noche, sin referencias concretas para su interpretación, y otra tomada en la cercana playa de Samil, con un chorro de agua cayendo de una fuente, en primer plano, y unos paseantes que apenas se adivinan. Al igual que en la fotografía de la carabela en la joyería, esta es de formato vertical y aparece dividida en dos mitades.

25 'I'm struck by how a man on the docks of Vigo, unloading a shipment of frozen fish from Argentina, resembles a conductor (are his eyes also closed?), wand in air (I think it's a roll of cardboard in his hand) - which raises the question of what forces are conducting this conductor in the bizarre fantasia of global shipping” Ben LERNER, "Ben Lerner on Allan Sekula's 'Fish Story", Frieze, 8 (Jannuary, 2019) [en línea], https://frieze.com/article/ben-lerner-allan-sekulas-fish-story [Consulta: 10 de julio de 2020].

26 "Unsuccessful fishing for sardines off the Portuguese coast", Allan Sekula: Fish Story, p.148. 
Sekula se referirá años después a la apertura que propicia la idea de secuencia, frente al carácter cerrado de la serie: la secuencia fotográfica puede ofrecer una alternativa al "modelo institucional dominante" que organiza las imágenes de acuerdo a una clasificación rígida -un modelo "curatorial y burocrático", el de la serie, propio del archivo ${ }^{27}$. La organización en secuencias y la introducción de textos permiten a la fotografía funcionar como una novela o una película, incluso con un nivel más alto de complejidad narrativa y una mayor apertura al juego de las interpretaciones ${ }^{28}$. La secuencia permite un registro del tiempo con intervalos variados, lo que, para Sekula, facilita la reproducción de esa fluidez y del movimiento del mar y del capital a través de un medio estático. Las raíces de este posicionamiento las podemos encontrar en autores soviéticos como Serguei Tretiakov, quien indicó en su día -en el marco de los debates sobre la utilización del arte al servicio de la causa revolucionaria- que, para una mayor eficacia política, la fotografía debía abandonar la estética de la imagen única y abrazar "la secuencia fotográfica sistemática"29.

Mensaxe nunha botella encaja perfectamente en el proyecto de Sekula para una nueva fotografía documental por la estrategia de aproximación a partir de una secuencia que recoge diversidad de facetas de una misma realidad, actuando por contraste, prescindiendo del elemento dramático y rechazando el "momento significativo". Las imágenes funcionan a partir de una lógica de colisión y complementariedad, y el acompañamiento de un texto contribuye al distanciamiento reflexivo.

La pieza del 9 de octubre de 1992 es un texto que, como dijimos más arriba, relaciona a Julio Verne con los tesoros de los galeones hundidos de Rande y la acumulación primitiva. Sekula se sirve de un fragmento del escritor Xosé Luis Méndez Ferrín, quien "captó la ironía de la búsqueda de Nemo en las aguas de Vigo" 30 . La riqueza siempre marcha, escribe Sekula refiriéndose a la economía de la pesca, el granito, "o la simple fuerza de trabajo emigrante" 31 . Aquí se recoge una percepción muy extendida por entonces en Galicia que alude al desequilibrio entre el potencial exportador de la comunidad y la escasa capacidad para generar valor añadido por la transformación de materias primas. Pero, además, estas palabras se escriben a principios de los noventa, años en los que la ciudad estaba sufriendo la dureza del proceso de reconversión naval que había destruido gran cantidad de puestos de trabajo y dejado una sensación de trauma colectivo en sus habitantes ${ }^{32}$.

Julio Verne situó uno de los episodios de 20.000 leguas de viaje submarino en la Ría de Vigo y puso al capitán Nemo a buscar los tesoros escondidos de Rande. Había escrito:

Aquí mismo se habían hundido los galeones cargados a cuenta del gobierno español. Aquí venía el capitán Nemo a proveerse, según sus necesidades, de los millones con que sostenía su Nautilus. Fue para él, para él solo, para quien América mandó esos preciados metales. Era él el heredero directo y sin partición de esos tesoros arrancados a los incas y a los vencidos por Hernán Cortés.

27 "Allan Sekula. Fish Story: Notes on the Work", en Documenta_11. Platform 5: Exhibition Catalogue [Kassel 2002], Okwui Enwezor (comis.), Hatje Cantz, Ostfildern-Ruit (catálogo de la exposición celebrada del 8 de junio al 15 de septiembre de 2002), 2002, pp. 582-583. Adaptación de Sekula de una entrevista en D. Risberg (ed.), Allan Sekula: Dismal Science Photoworks 1972-1996, Illinois State University, 1999.

28 Idem.

29 Buchloh cita un texto de Tretiakov de 1931: "Al igual que construimos sistemáticamente, también debemos fotografiar sistemáticamente. La secuencia y la observación fotográfica a lo largo del tiempo, éste es el método". Benjamin BuCHLOH, Formalismo e historicidad. Modelos y métodos en el arte del siglo XX, Madrid, Akal, 2004, p. 139.

30 Allan SeKulA, "Mensaxe nunha botella", en V Fotobienal de Vigo 1992, Manuel Sendón y Xosé Luis Suárez Canal (comis.), Vigo, Concello de Vigo / Centro de Estudos Fotográficos (catálogo de la exposición celebrada del 29 de octubre al 29 de noviembre de 1992), 1992, p.25. El texto aparece reproducido en inglés en SEKULA y LoRENZ, 2002, p.141.

31 Idem.

${ }^{32}$ Los años centrales de la década de los 80 fueron especialmente duros en la ciudad de Vigo por la incidencia de la reconversión naval. Ante la falta de encargos y problemas en la gestión de los grandes astilleros, se puso en marcha un plan de ajuste que llevó a reducir drásticamente las plantillas, perdiendo su trabajo más de 4.000 personas. Los efectos sociales fueron especialmente intensos en los años posteriores. 
- ¿Sabía usted, señor profesor -me preguntó, sonriendo- que la mar contiene tantas riquezas?

- Sabía que se calculaba en dos millones de toneladas la plata que el mar tiene en suspensión -respondí.

- Indudablemente, pero para extraer esa plata los gastos serían muchísimo mayores que las ganancias. Aquí, por el contrario, no tengo que recoger sino lo que los hombres perdieron, y no solamente en esta bahía de Vigo, sino también en miles de escenarios de naufragios, cuyos lugares tengo señalados en mi mapa ${ }^{33}$.

Pero para Ferrín, Nemo es simplemente un nihilista, "otro demiurgo externo y destructivo" que pasa cerca de la costa y se va ${ }^{34}$. El escritor gallego había escrito -poco antes de la llegada de Sekula a la ciudad- acerca del interés que el tema de los galeones hundidos en Rande había suscitado en el París de la segunda mitad del XIX. Entonces se crearon compañías para la prospección de fondos marinos que llegaron a explorar el interior de la ría ${ }^{35}$. Sekula recoge esta idea de la riqueza que no queda y la traslada a la figura de un heroico capitán que se cree heredero de las riquezas americanas, ese botín histórico que Marx pone en relación con la "acumulación primitiva" del capitalismo. El potencial crítico que Nemo pudiera llegar a tener con respecto a la riqueza expoliada de América por los españoles se pierde, es estéril: queda un sentido aristocrático en el navegante, en su relación con los tesoros, robados primero y después echados a perder: "Su proyecto aparece bloqueado, por un lado, por su nostalgia aristocrática y, por otro, por un lema abstracto y futurista de flujo perpetuo dentro del flujo" 36 .

Diez años después, en el marco de una exposición que recogía el trabajo de los fotógrafos participantes en "Vigovisións", Marta Gili escribirá sobre esta serie de Sekula, poniéndola en relación con la que acababa de realizar por encargo del periódico La Vanguardia sobre el Prestige. El texto de Sekula sobre Nemo y los tesoros perdidos de Rande apuntaría a una desconfianza nacida de una historia de desilusiones: la ciudad ya no cree en "aquello que no puede ver con sus ojos o palpar con sus manos"; 37 ni sueños ni mitos, en una ciudad que ha pasado por una crisis industrial traumática. Para Sekula, el Capitán Nemo continua en el fondo del mar. Pero Vigo, escribe Gili, no va a sumergirse para verlo, "demasiado ha visto ya flotando últimamente sobre sus aguas", y probablemente ese desasosiego colectivo de las fotografías de 1992 se está haciendo de nuevo vigente ante los acontecimientos derivados de la marea negra en $2002^{38}$.

\section{Historia de peces, trabajo y circulación de las mercancías}

La propuesta de Sekula era importante para los organizadores de la Fotobienal, por lo que implicaba de replanteamiento crítico con respecto a la tradición de la fotografía documental. Consideraron la importancia de no convertir a la víctima en objeto de contemplación, de ahí el trabajo de contextualización y estu-

\footnotetext{
33 Julio Verne, 20.000 leguas de viaje submarino, Madrid, Diario El País, 2004, p. 315 (traducción de Antonio Álvarez Práxedes). En la pieza de "Mensaxe nunha botella" se cita un fragmento de la obra del autor francés a partir de una edición inglesa de 1908.

34 SeKUla, 1992, p.25. El texto aparece reproducido en inglés en SEKULA y Lorenz, 2002, p.141.

35 “Jules Verne, en texto inolvidable, hace entrar al capitán Nemo en la 'Bahía de Vigo' a extraer el oro submarino, con el cual aquel nihilista subvencionaba los movimientos de liberación nacional que se levantaban contra el imperio inglés. En la segunda mitad del siglo XIX, los galeones de Vigo eran objeto de especulación constante en París. Recuerda el libro 'Les galions de Vigo', París, 1873. En 1870 se hicieron prospecciones extractivas y en 1872 se creó una 'Entreprise de sauvetage' para hacerse con el oro. Creo que estas compañías fueron sobre todo operaciones de alta estafa para engañar a incautos ambiciosos. Pero la quimera del oro, la fascinación del tesoro oculto, funcionó”. Xosé L. MÉndez Ferrín, "Diálogo de Lampetusa y Sponsor. Sobre la cara y la cruz de la ciudad de Vigo”, en J. GiL, X. L. MÉndez Ferrín, Vigo: fronteira do Alén, Vigo, Ir Indo Edicións, 1989, p. 17.

36 SeKula, 1992, p. 25.

37 Marta GILI, "Territorios para escuchar", en Vigovisións, Manuel Sendón y Xosé Luis Suárez Canal (comis.), Vigo, Museo de Arte Contemporánea (MARCO) (catálogo de la exposición celebrada del 10 de abril al 8 de junio de 2003), 2003 , p. 37.

38 Ibidem, p. 38.
} 


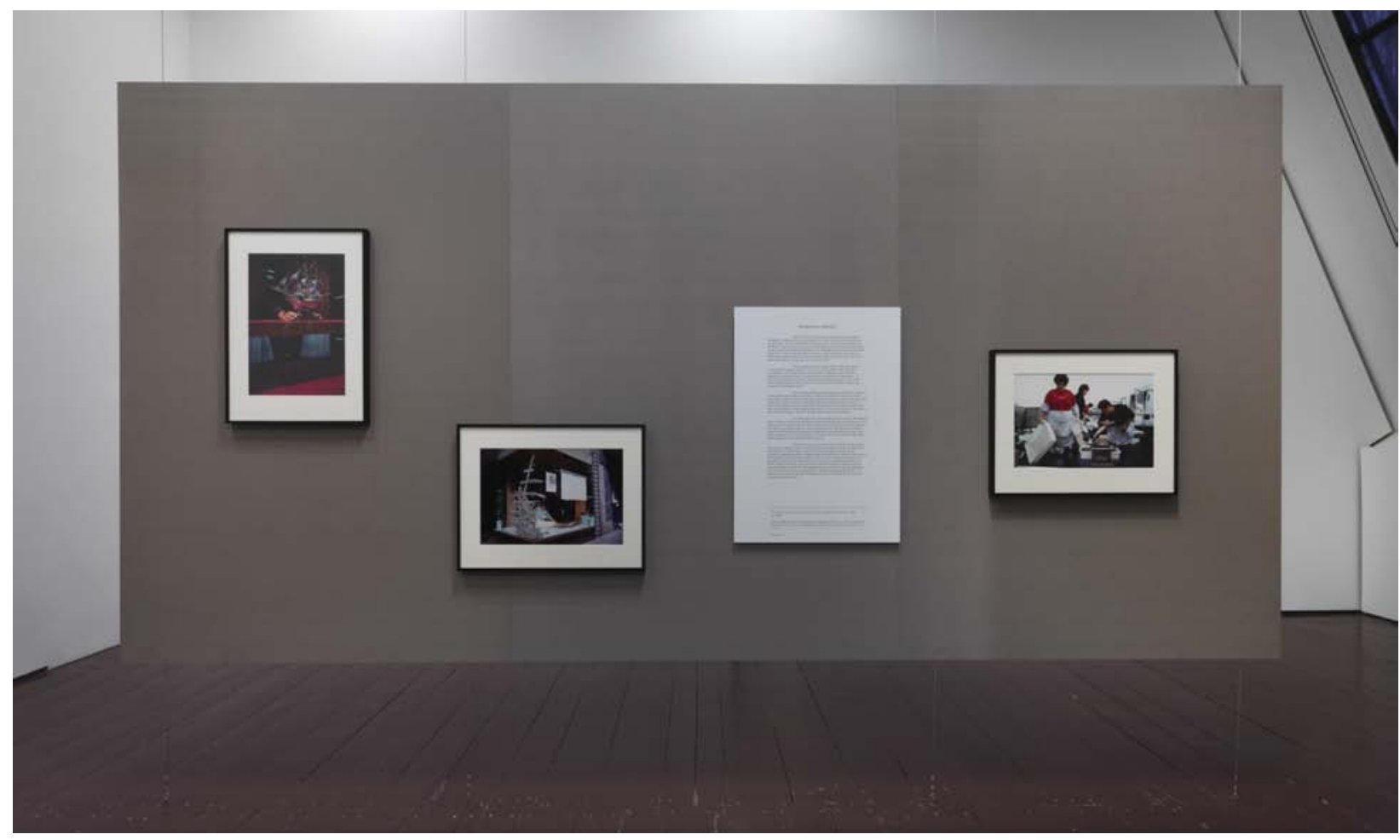

Fig. 6. Vista del montaje de las fotografías de Mensaxe nunha botella en la exposición Allan Sekula - OKEANOS, 2017, Thyssen-Bornemisza Art Contemporary, Viena. Fotografía: Jens Ziehe| TBA21.

dio previo. La inclusión de textos que aclaran las situaciones específicas, o introducen elementos para la discusión, va en esta misma línea (fig. 6). Poco después, Mensaxe nunha botella se presentará en el New Museum de Nueva York, y una selección de las imágenes captadas en Vigo conformará el capítulo 5 de un libro de Sekula sobre trabajos vinculados con el mar: Fish Story $(1995)^{39}$.

Como en otras ocasiones, Sekula traslada a formato libro una secuencia elaborada dentro de un contexto específico. Para el libro y las exposiciones posteriores escogerá un grupo de siete fotografías realizadas en Vigo, de las que cuatro coinciden con las expuestas en la Fotobienal. Message in a Bottle -con título ya en inglés- es la selección que comercializará su galería californiana ${ }^{40}$.

Fish Story es un foto-ensayo compuesto por varias secuencias de imágenes intercaladas con textos que documenta trabajos relacionados con la economía marítima, desde el tráfico de mercancías hasta la construcción naval, pero también el estado de las infraestructuras portuarias castigadas por la desindus-

39 'La primeira versión de 'Message in a Bottle' (1992/94) fue mostrada en 1992 en la Fotobienal de Vigo y publicada con texto en gallego en el catálogo de la exposición. Poco después sería exhibida, en 1993, en el New Museum of Contemporary Art de Nueva York". SEKula y Lorenz (eds.), 2002, p.202 (traducción del autor). En 2002 las fotografías se expondrán en formato proyección de diapositivas en Kassel (Alemania), en el marco de la Documenta 11.

${ }^{40}$ Hoy la secuencia completa está presente en la colección Thyssen Bornemisza Art Contemporary, de Viena, que la presenta como registro de "los cambios y abandono de la industria de pesca española". Se trata de una serie de piezas que se corresponde con la versión para Fish Story, algo diferente, pues, de la presentada en Vigo en 1992, pero conserva el texto sobre el Capitán Nemo (ahora en inglés) y la lista de fotografías. "Allan Sekula. 'Message in a Bottle'. Chapter 5, Fish Story, 1992/1994". Thyssen Bornemisza Art Contemporary. Collection. [en línea], https:/www.tba21.org/\#item—messageinabottle—1411 [Consulta: 10 de julio de 2020]. 
trialización. El texto de Michael Gibbs recogido en el catálogo de la Fotobienal de 1990 aludía ya a la investigación que Sekula estaba llevando a cabo en las áreas portuarias, donde la industria y la clase obrera estaban siendo desplazadas por el comercio y las inversiones inmobiliarias ${ }^{41}$. Tanto en este como en otros trabajos, Sekula abordará el proceso de desaparición de las viejas instalaciones -sorprende la dureza de los escenarios y su decrépita magnificencia- y la emergencia de nuevos polos de poder económico. Marineros y trabajadores de astilleros son desplazados por las nuevas tecnologías y los "súperpuertos", indica Benjamin James, están cada vez más lejos del centro de las ciudades; las fotografías suponen un registro de este "proletariado cosmopolita del mar" que parece en proceso de desaparición ${ }^{42}$. Para Debra Risberg, Fish Story es un proyecto nacido de la conciencia de que, desde la década de los setenta, se estaba consolidando una nueva fase del capitalismo trasnacional que descansaba en buena medida en el transporte por mar de mercancías en contenedores ${ }^{43}$. El trabajo de Sekula se consagra a documentar espacios fuertemente impregnados de ideología, desde puertos y zonas de frontera hasta áreas residenciales. Y, en este proceso, Sekula siente atracción por zonas que registran fuertes alteraciones en los flujos del capital: ciudades castigadas por la reconversión naval (Gdansk o Glasgow) y otras en proceso de crecimiento y consolidación (como Seúl, en Corea) ${ }^{44}$. El conjunto realizado en el marco de la Fotobienal proporcionaría materiales para este proyecto global, incidiendo en los escenarios y los efectos de la desindustrialización.

En la introducción de Fish Story relata sus recuerdos como joven criado en zona portuaria, en California: cada barco se podía identificar por su carácter nacional y así se distinguían los barcos noruegos, limpios y ordenados, de otros como los griegos, más descuidados ${ }^{45}$. Pero hoy esto ya no funciona, explica Sekula, porque los barcos van bajo banderas de conveniencia, son construidos y reparados en países diferentes, y las tripulaciones son por lo general de países lejanos, como Filipinas u Honduras. Los puertos acogen mercancías en grandes cantidades, pero las ocultan a la mirada, encerradas en contenedores. Todo está regularizado, racionalizado, automatizado: fruta, pescado, componentes electrónicos, cocaína... Lo que uno ve en los puertos es el "movimiento concreto de los bienes"46, y este movimiento solo puede ser explicado a través el recurso a la abstracción.

Fish Story responde, pues, a un programa de revisión de los parámetros de la fotografía documental y para Hal Foster es un ejemplo relevante del giro etnográfico del arte de los años 90. En el ensayo "El artista como etnógrafo" destaca el "empleo crítico de los modos documentales" en Sekula, con proyectos que apuntan a problemáticas y contextos concretos, pero que plantean una dimensión geopolítica global ${ }^{47}$. Foster cita tres trabajos realizados por el fotógrafo entre los años 80 y los 90: "Esbozo de una lección geográfica" (1983), sobre las fronteras de Alemania y la política de la Guerra Fría, "Notas canadienses" (1985), sobre minería y finanzas, e "Historias de peces" (1995), sobre comercio marítimo y economía global. "Con estas 'geografías imaginarias y materiales del mundo capitalista avanzado' [Sekula] esboza un 'mapa cognitivo' de nuestro orden global', pero siempre desde un planteamiento dialéctico que problematiza la relación entre imagen y texto ${ }^{48}$.

\footnotetext{
41 Michael GibBs, 1990, p. 68.

42 Benjamin JAMES, "Sympathetic Materialism: Allan Sekula's Photo-Works, 1971-2000”, Tesis Doctoral, Berkeley, University of California, 2018, p. 128.

43 RisBerG, 1999, p. 238.

44 Ibidem, p.247.

45 SeKula y Lorenz, 2002, p. 12.

46 Idem.

47 Hal Foster, El retorno de lo real, Madrid, Akal, 2001, p.194.

48 Idem.
} 
Para W.J.T. Mitchell, la obra de Sekula "tiende a fusionar el 'realismo crítico' de Lukács con cierto énfasis en las condiciones del trabajo y cierto interés en exponer fotográficamente un mundo que se pasa por alto"49. Y, sin embargo, no se descuida la belleza y se percibe el cuidado puesto en la elaboración de la imagen. Mitchell se interesa por una fotografía de Fish Story, una imagen fascinante que pertenece a la secuencia introductoria, expuesta en la Fotobienal de Vigo de 1990 (fig. 7). Se trata de una llave inglesa sobre una mesa sucia que intuimos abandonada, la llave ha sido movida recientemente y deja su rastro en la mesa. Una fotografía llamativa por su simplicidad, que ejemplifica la noción de "realismo social" con la que caracteriza el trabajo de Sekula, pero también se acerca al "realismo crítico" de György Lukács ${ }^{50}$.

\section{Ante la marea negra}

Allan Sekula volvió a Galicia en diciembre de 2002, recorriendo la costa y documentando las labores de limpieza derivadas del accidente del petrolero Prestige ${ }^{51}$. La nefasta gestión llevada a cabo por las autoridades provocó que el vertido no se atajase a tiempo y se fuese extendiendo una gran mancha por el litoral. El fotógrafo norteamericano explica así su reacción al acontecimiento:

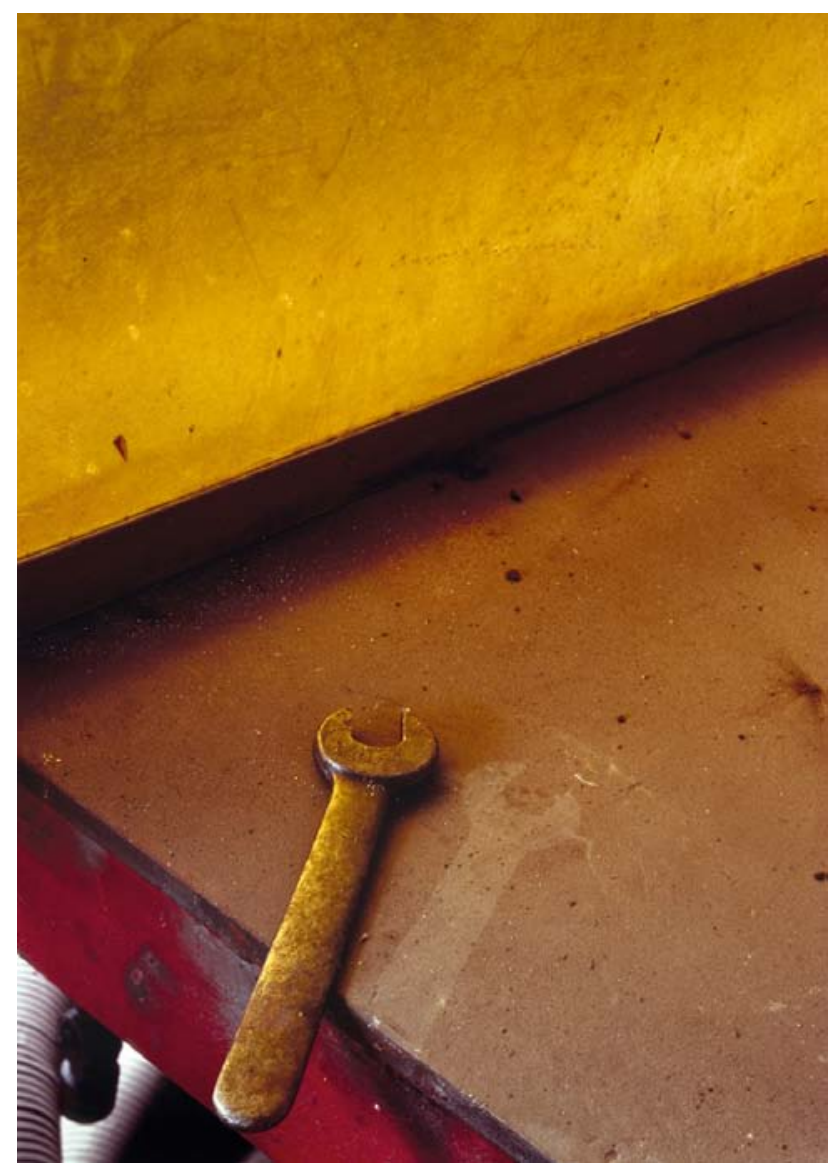

Fig. 7. Allan Sekula, Cabina de soldador en un astillero en bancarrota. Dos años después de cerrar. Puerto de Los Ángeles, San Pedro, California. Julio de 1991, de la serie Fish Story (1989-95).

A mediados de noviembre de 2002, el Prestige se partió por la mitad cerca de la costa de Galicia. Tuve la intuición de que se trataba de una calamidad con una tremenda resonancia, con efectos políticos impredecibles, y pensé en volver a Vigo, donde había hecho un reportaje sobre la pesca y otros aspectos de la economía local diez años antes para uno de los primeros capítulos de Fish Story (...). Como si me hubiera leído el pensamiento, el artista y crítico barcelonés Carlos Guerra [sic.] contactó conmigo al día siguiente para invitarme a realizar un proyecto de final abierto sobre el vertido, para el suplemento cultural del periódico La Vanguardia ${ }^{52}$.

49 W.J.T. Mitchell, La ciencia de la imagen, Madrid, Akal, 2019, p.66.

50 "La fotografía ejemplifica el realismo social en el sentido de que no se trata de una sola obra, sino que es parte de todo un mundo documentado con amoroso detalle, tanto por otras fotografías como por el texto que las acompaña". Mitchell ilustra la noción de [Northrop] Frye de "bajo realismo mimético" porque hace énfasis en el mundo del trabajo. Refleja el 'realismo crítico' en el sentido de Lukács en cuanto que es el tipo de imagen que solo se le ocurriría a alguien ajeno al mundo que Sekula está documentando". Idem.

51 El Prestige, un monocasco liberiano con bandera de las Bahamas y operado por una naviera griega, se accidentó el 13 de noviembre de 2002 frente a las costas gallegas. Llevaba un cargamento de 77.000 toneladas de fuelóleo. Las autoridades ordenaron alejar al buque (contra la opinión de expertos en seguridad marítima), siendo entonces remolcado a alta mar: primero en dirección suroeste y luego en dirección norte. El 16 de noviembre comienza a llegar chapapote a la Costa da Morte (A Coruña). El barco se parte en dos y se hunde el 19 de noviembre, provocando una marea negra que afectará a más de 2.000 km de costa entre el norte de Portugal y el suroeste de Francia.

52 Allan Sekula, citado en BRIGHT, 2005, p.188. 


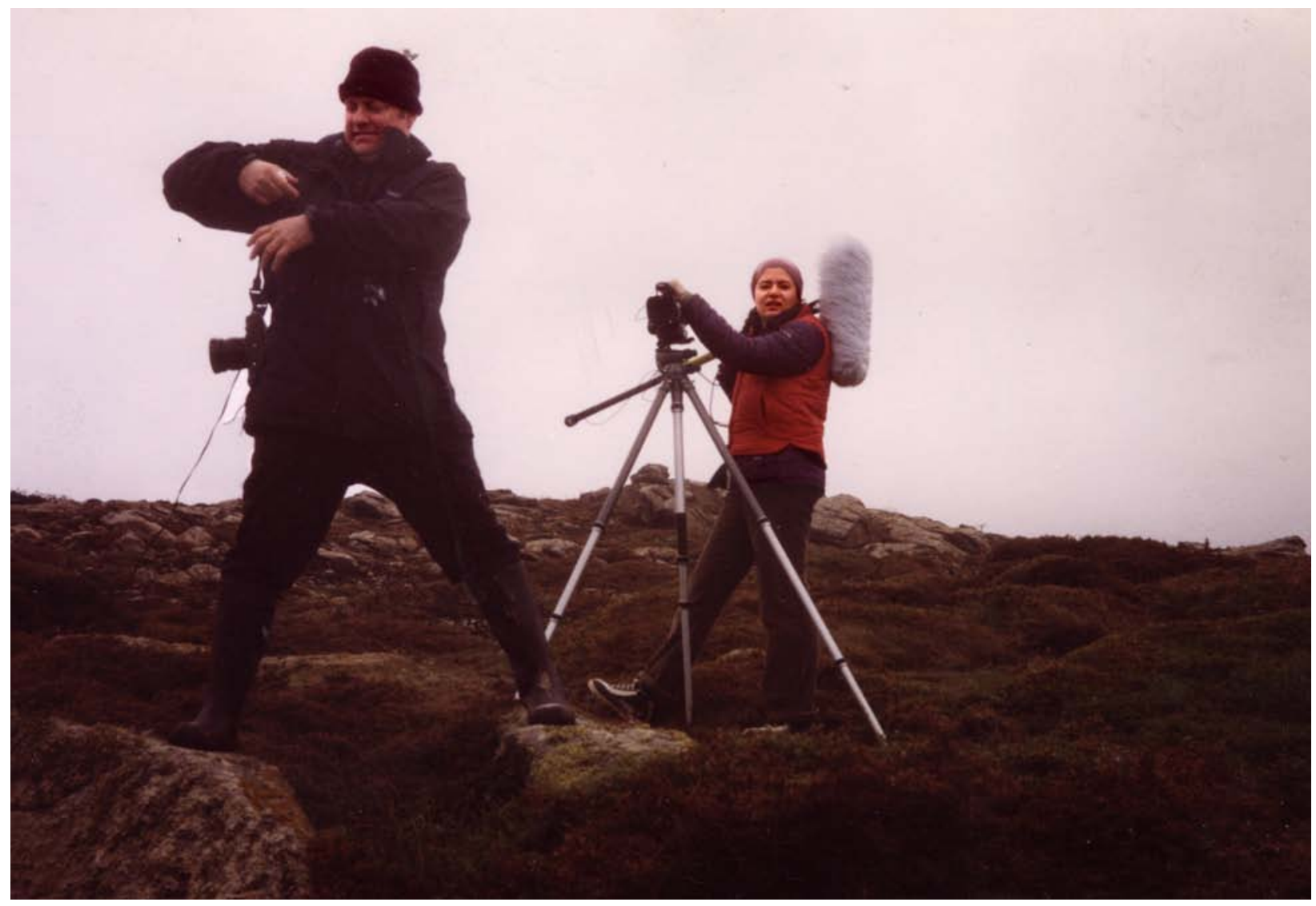

Fig. 8. Allan Sekula y Olaia Sendón, en el Coído de Touriñán (ACoruña), diciembre de 2002. Fotografía de Manuel Sendón.

Ante la carencia de medios para atajar el vertido, la ocultación de información y la nefasta gestión por parte de las autoridades, cientos de marineros, mariscadoras y voluntarios comenzaron a organizarse y a actuar, frenando en el mar el avance del vertido y limpiando las zonas afectadas de la costa. La movilización alcanzó un nivel espectacular en pocos días y tuvo una dimensión política de gran alcance, con manifestaciones multitudinarias promovidas por el colectivo Nunca Máis, acciones coordinadas por profesorado de centros de primaria y secundaria, y un trabajo ingente de producción cultural a cargo del colectivo Burla Negra: carteles, audiovisuales, conciertos, recitales de poesía, libros, exposiciones y merchandising ${ }^{53}$.

Carles Guerra actuó como enlace entre periódico y fotógrafo, y transmitió indicaciones sobre el encargo: no habría condiciones, el grado de libertad iba a ser amplio, porque lo que produjese iría para las páginas del suplemento cultural. Estaban todos de acuerdo en que lo que hiciera Sekula no iba a ser fotoperiodismo ${ }^{54}$.

A su llegada a Galicia, Sekula se reencontró con Manuel Sendón, que lo puso en contacto con el artista Fran Herbello ${ }^{55}$. Este lo acompañó, junto con Carles Guerra, los primeros días por la península del Morrazo, Islas Ons y Cíes (Pontevedra). A continuación, el recorrido se desarrollaría por la Costa da Morte

53 Ver, sobre el despliegue creativo generado con motivo de estas movilizaciones: Nunca Máis. A voz da cidadanía I, Difusora de Letras, Artes e Ideas, Ourense, 2003; el número especial “Unha Gran Burla Negra”, de la revista Luzes, 65 (2019), pp. 6-48; y la web de la Asociación Cultural Unha Gran Burla Negra: http://unhagranburlanegra.gal/ [Consulta: 10 de julio de 2020].

54 Carles Guerra, entrevista personal, en Barcelona, 22 de julio de 2019.

55 Manuel Sendón, entrevista personal, en Vigo, 1 de marzo de 2018. 
(A Coruña), junto a Manuel y su hija Olaia Sendón (fig. 8). De la incursión saldrá el reportaje "Marea negra: fragmentos para una ópera", publicado en La Vanguardia, la serie Black Tide/Marea negra y una parte sustancial de las imágenes de su película The Lottery of the Sea (2006). Esta fue concebida como un ensayo a partir de una investigación de varios años - un poco al modo de Fish Story-, sobre la idea de riesgo en la economía global y las nuevas formas de resistencia popular. De una duración total de 179 minutos, 41 son grabación realizada en Galicia ${ }^{56}$.

"Marea negra: fragmentos para una ópera" es una composición formada por 19 fotografías y un texto del propio Sekula, publicada como reportaje de cabecera del suplemento "Culturas" de La Vanguardia, el 12 de febrero de $2003^{57}$. Las imágenes pasarán ese mismo año a conformar una serie positivada y comercializada por la galería Christopher Grimes, de Santa Mónica (EEUU) bajo el título Black Tide ${ }^{58}$. Las fotografías se agrupan en dos grandes "categorías" en palabras de Peter Frank: una es la que tiene como protagonista al vertido en sí -el viscoso y negro chapapote- y la otra se centra en los voluntarios, unas veces trabajando concentrados, otras veces ansiosos, exhaustos, y en alguna toma incluso relajados y distraídos ${ }^{59}$. La forma final que adoptó este encargo, un libreto para una ópera imaginaria a representar 30 años después del desastre, fue una sorpresa para los responsables de La Vanguardia, pero entraba en los presupuestos estéticos del fotógrafo de poner distancia a través de un relato más o menos ficcional (con texto escrito incluido) ante los acontecimientos ${ }^{60}$.

Sekula usó una cámara de formato medio - una Leica pequeña- y una cámara de vídeo, y durante la realización del proyecto no hacía demasiadas fotos ${ }^{61}$. Bastante a menudo hacía dos o tres disparos consecutivos, aspecto este que se refleja en cierto modo en el resultado final, pues algunas de las piezas que componen Black Tide son dípticos y trípticos, como el de la voluntaria captada, primero, en un momento de descanso con la mirada perdida y luego, ya consciente de que la estaban fotografiando, sonriendo ${ }^{62}$ (figs. 9 y 10). La selección final de las fotos fue responsabilidad de Sekula. Tan sólo hubo conversaciones con la redacción del periódico para la distribución de algunas fotos ${ }^{63}$.

Sekula había establecido previamente el vínculo entre lógica del deseo del capitalismo neoliberal y catástrofe; el colapso se adivina en series anteriores como Titanic's Wake (1998-99), con la imagen de postal del Guggenheim de Bilbao "oscurecida" por sus vínculos con la industria química, que no estaba tan lejos de las catástrofes de Seveso y Bhopal ${ }^{64}$. Cuando el fotógrafo realizaba este trabajo pudo ver, en un terminal de contenedores próximo, bidones con ácido fluorhídrico, un agente químico de gran toxicidad usado para el tratamiento de las láminas de titanio del museo, también habitual en la industria aeroespacial.

${ }^{56}$ La película recoge imágenes de países como Japón, Panamá, España y Estados Unidos, tomadas a lo largo de varios años. Las fotografías de "Marea Negra" están datadas entre el 19 y el 24 de diciembre de 2002.

57 Allan SeKula, "Fragmentos para una ópera", Culturas. La Vanguardia (12 de febrero de 2003), pp. 2-7.

58 Se pudieron ver primero en el Centre de Cultura Contemporània de Barcelona en julio de 2003 y en la galería Christopher Grimes, en Santa Mónica, en noviembre-diciembre de ese mismo año. La serie se encuentra en la actualidad en las colecciones de MUSAC (León), Thyssen-Bornemisza Art Contemporary (Viena) y Museo Nacional Centro de Arte Reina Sofía (Madrid).

59 Peter Frank, "Allan Sekula at Christopher Grimes", Art in America (diciembre de 2003), p.115.

60 Carles Guerra, entrevista personal, en Barcelona, 22 de julio de 2019.

61 Idem. Olaia Sendón, que lo ayudó en las grabaciones ocupándose de la pértiga, recuerda que, en general, el fotógrafo no se movía guiado por una planificación previa de los itinerarios, salvo el día que se dirigieron al depósito del chapapote, en Lendo (A Coruña). Olaia Sendón, entrevista telefónica, 17 de octubre de 2019.

62 Estas imágenes formaron finalmente un díptico en Black Tide, pero en la versión para La Vanguardia solo se publicó la primera.

63 Especialmente esto afectó a la composición del marinero tomando sopa y la balsa de chapapote (dispuestas en formato vertical, tanto en La Vanguardia como en Black Tide); esta composición aparece cortada en primera página del suplemento. Carles Guerra, entrevista personal, en Barcelona, 22 de julio de 2019.

64 Allan SeKula, "Between the Net and the Deep Blue Sea", October, 102 (otoño de 2002), p. 21. Se hace referencia a los accidentes de las plantas químicas de Seveso (Italia) en 1976, y Bhopal (India) en 1984. 


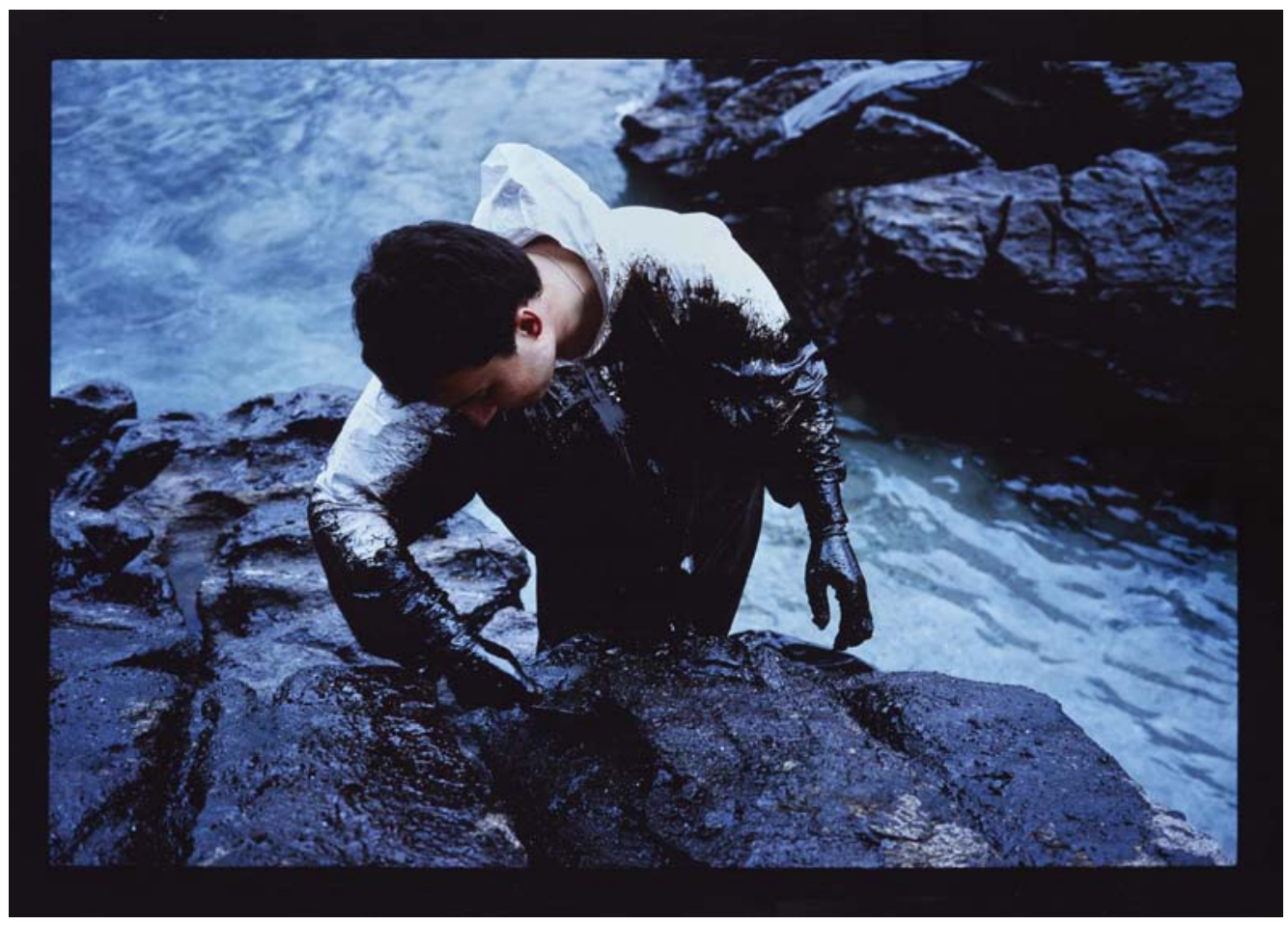

Fig. 9. Allan Sekula, Voluntario en la orilla [Islas Cíes, 20/12/2002], de la serie Black Tide/Marea Negra, 2002-2003, cibachrome sobre poliéster, con marco: 75,4 x 102,9 cm, MNCARS, Madrid (depósito indefinido de la Fundación Museo Reina Sofía).

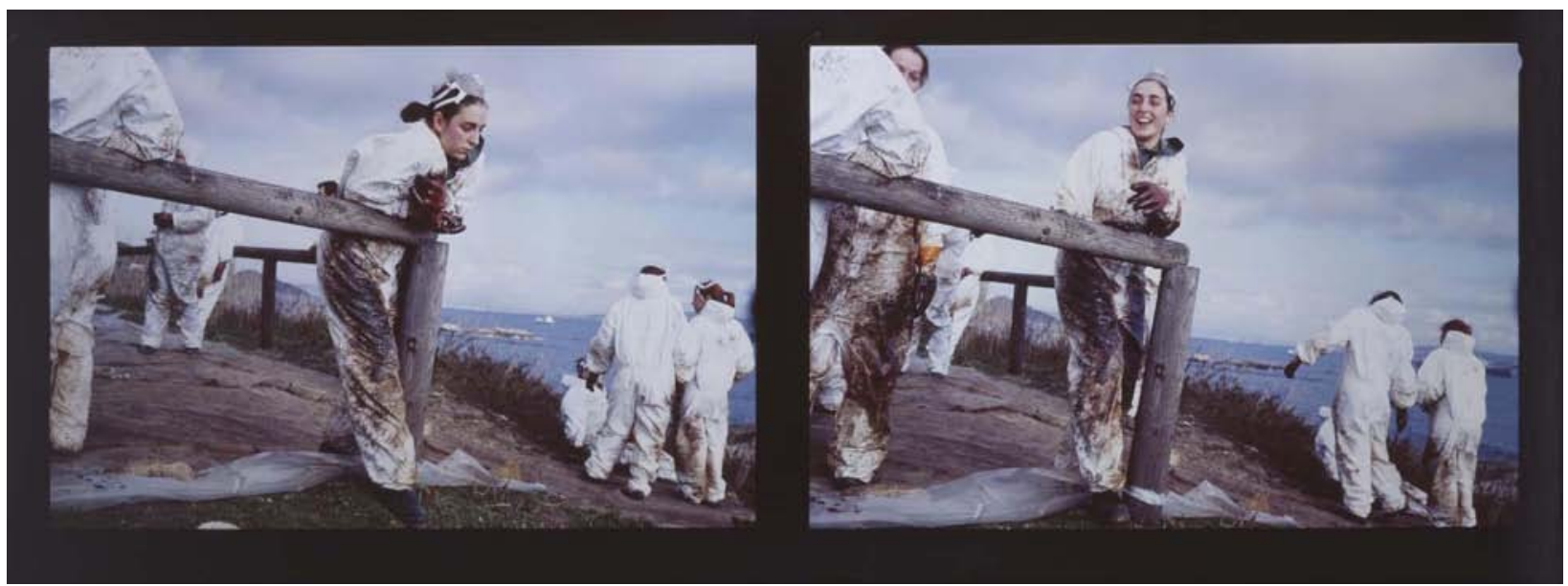

Fig. 10. Allan Sekula, Voluntaria observando, voluntaria sonriendo, de la serie Black Tide/Marea Negra, 2002-2003, cibachrome sobre poliéster, 52,5 x 76,5 cm y 52,5 x 77,5 cm, Colección MNCARS, Madrid.

El trabajo incansable, insistente y repetitivo de los voluntarios limpiando de chapapote el litoral sirvió de inspiración para el fotógrafo, remitiendo a un modelo clásico que, en un primer momento, podría desconcertar a los conocedores de su obra. Grupos de voluntarios vestidos de blanco de arriba abajo, con protecciones Tyvek y máscaras ocultando las caras, compondrían un coro en la tragedia de la lucha contra la contaminación. Aparece entonces la referencia a Sísifo, a través de un pequeño poema escrito en gallego 
por el fotógrafo para acompañar las fotografías publicadas ${ }^{65}$. Carles Guerra señala en un texto aparecido en el mismo suplemento que el fotógrafo insistió durante esos días en la idea de "una gran coreografía" que se desplegaba a través de grupos de voluntarios enfundados en monos blancos, trabajando incansablemente en las costas contaminadas. ${ }^{66} \mathrm{Y}$ el propio Sekula aludirá a un elemento dramático en los acontecimientos:

Los tremendos esfuerzos, como de Sísifo, para contener el vertido, tenían todo el drama de una ópera, especialmente si tenemos en cuenta la curiosa indiferencia y pasividad del entonces gobierno de derechas en España. Yo pensaba, como es natural, en un enfoque que fuera lo contrario del fotoperiodismo, especialmente crítico con los efectos duraderos en el tiempo de los derrames de crudo, que normalmente pasan desapercibidos en los titulares de prensa ${ }^{67}$.

Tanto en "Marea negra" como en la película The Lottery of the Sea se pone en evidencia la contraposición entre la desastrosa gestión de la catástrofe por parte de las autoridades y el trabajo desinteresado y comprometido de los voluntarios (figs. 11 y 12). En la película, Sekula intercala declaraciones de voluntarios que hablan a la cámara, y son frecuentes las críticas hacia los políticos, en ocasiones desde el sarcasmo, como cuando un marinero que regresa de trabajar en las tareas de limpieza se lamenta: "Parece mentira... Hay tecnología para llegar a Marte y no hay para limpiar toda esta mierda"68.

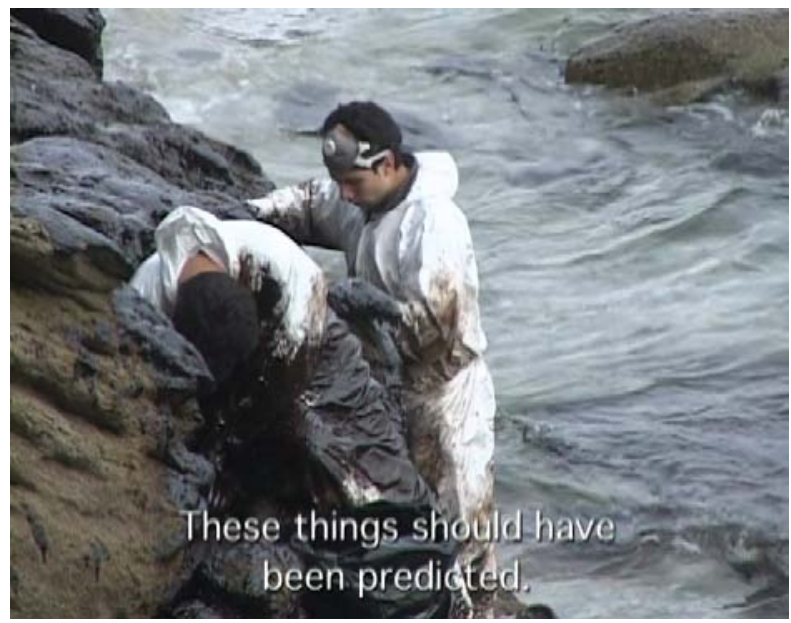

Fig. 11. Allan Sekula, The Lottery of the Sea, 2006, cine en formato digital, $178 \mathrm{~min}$. (1:26:20), Colección MNCARS, Madrid.

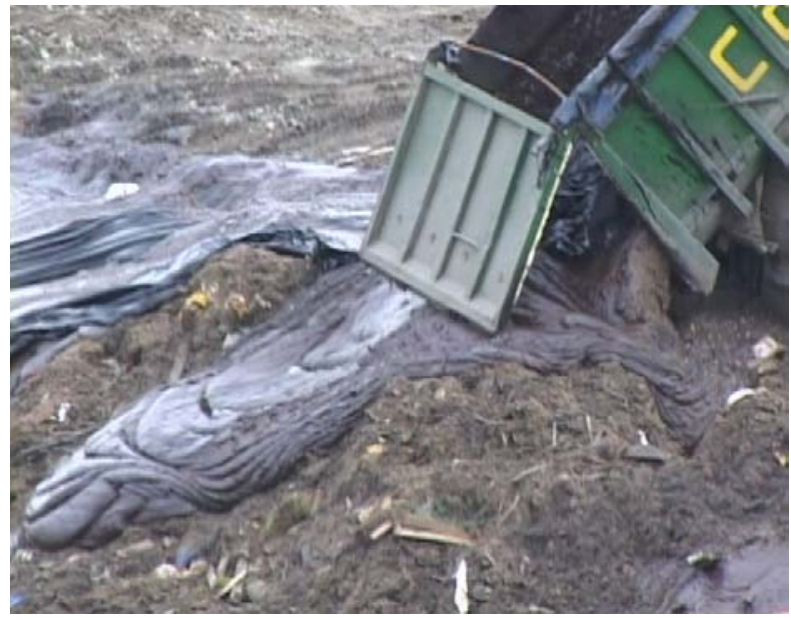

Fig. 12. Allan Sekula, The Lottery of the Sea, 2006, cine en formato digital, $178 \mathrm{~min}$. (1:42:55), Colección MNCARS, Madrid.

65 "CANCIÓN DO SÍSIFO COLECTIVO: O prestixio de Sísifo / nunca máis / unha vez máis / nunca máis / unha vez máis". SEKUlA, 2003, p.4. Este pequeño poema juega con el motivo de la repetición incesante de los trabajos de limpieza (voluntarios limpian en marea baja, y todo se vuelve a ensuciar con la marea alta), y con el nombre del movimiento social de protesta por la gestión de la catástrofe.

66 "A medida que recorríamos Rías Baixas y Costa da Morte, la imagen que más le oí nombrar se refería a una gran coreografía. A veces espontánea, otras, dirigida: pescadores recogiendo fuel con sus botes, voluntarios organizándose por su cuenta y jóvenes del ejército desfilando por las playas. O más tarde, el 23 de enero, cuando 45.000 escolares formaron una cadena humana entre Laxe y Muxía”. Carles GuERrA, "Sekula en Galicia. Tras los pasos de Evans y Agee", Culturas. La Vanguardia (12 de febrero de 2003), p.7.

67 Allan Sekula, citado en BRIGHT, 2005, p.188.

68 The Lottery of the Sea (2006), 1:32':10”. En gallego en el original. 
En el libreto de Sekula, esta contraposición es más que evidente, adoptando un tono que, por momentos, se aproxima a la caricatura al modo del teatro de Bertolt Brecht: "El Ministro de Defensa, que ha estado pasando revista al coro, anuncia que las playas están esplendorosas. Llega un ayudante con una tumbona, una sombrilla y una bebida tropical. La mitad del Coro continua en posición de firmes, mientras la otra mitad trabaja"69.

Se han señalado para estas obras referencias literarias concretas, como la Ópera de tres peniques de Brecht, La Estética de la resistencia de Peter Weiss -con la escena ante el Altar de Pérgamo que apunta al tema de la auto-educación-y el Mito de Sísifo de Albert Camus ${ }^{70}$. En "Marea negra: fragmentos para una ópera" se combinan un esquema formal cercano al teatro de Brecht y la alusión al tema de las luchas inacabadas del Sisifo de Camus. Por aquí se abre una vía de interpretación que enlaza con las luchas anti-globalización. Esta tesis es defendida por Carles Guerra y por Gabriele Mackert. Esta última señala que, además de las reminiscencias de la tragedia clásica, se debe poner el acento en los movimientos de protesta antiglobalización: la apariencia de los grupos de voluntarios enfundados en la ropa de protección remite al movimiento italiano de los Tute Bianche que también se sirvió -como en el caso gallego- de las redes sociales para articular sus acciones ${ }^{71}$. Esta dimensión política de la movilización será destacada por Sekula, quien en una entrevista publicada en 2005 explica que interpretó lo que vio en Galicia como un "punto de ruptura" en la hegemonía del modelo neoliberal: "La idea que surge, tanto del proyecto para el periódico como de la película, es la de que aquí había un nuevo tipo de resistencia popular frente a la negación neoliberal del riesgo, un "Sísifo colectivo"'72.

¿Hasta qué punto esta serie es distinta de lo realizado anteriormente por Sekula? El fotógrafo parece llevarnos al terreno de la mitología, acentuando el componente épico de la historia, con lo que podría superar planteamientos anteriores de corte más analítico y aproximarse aún más a otras formas artísticas, como la literatura y las artes escénicas.

Algunos de sus últimos trabajos se caracterizan por la toma de posición, por la implicación del artista en los acontecimientos. Si bien el elemento narrativo ya aparecía -aunque alterado por una sintaxis compleja- en series anteriores como Aerospace Folktales (1973) o This Ain't China. A Photonovel (1974), parece como si la distancia analítica desapareciese ahora, y en su lugar se mostrase una cercanía con los hechos que llega a ser hasta emotiva. El mito, a través de un héroe trágico (Sísifo o Hércules) se integra en una fase nueva de su trabajo que ya no documenta flujos de mercancías o un mundo que se desvanece. El cuerpo social pasa ahora a la acción, no como el objeto pasivo de las transacciones y los procesos económicos, sino como agente activo. Ante un acontecimiento concreto, dramático -en este caso el Prestige-, el fotógrafo opta por un acercamiento a los hechos mediado por el recurso a la ficción: una lectura en clave teatral $^{73}$. Tal vez esto ayudó a la última vuelta de tuerca de su revisión de la fotografía documental. Esta obra, como señala Carles Guerra, está muy relacionada con Waiting for Tear Gas (1999-2000), que trata de las luchas antiglobalización en la ciudad de Seattle contra la cumbre del G8. Se trata de fotografías implicadas, con un fotógrafo copartícipe ( $\sin$ flash, sin teleobjetivo, sin pase de prensa) y es el inicio de las incursiones de Sekula en las movilizaciones sociales ${ }^{74}$.

69 SeKula, 2003, p. 6.

70 Carles Guerra, entrevista personal, en Barcelona, 22 de julio de 2019; Gabriele MACKERT, "Sisyphus' Prestige. On Allan Sekula's Marea Negra. Fragmentos para una Ópera”, en D. Zyman y C. Scozzari, (eds.), Allan Sekula. Okeanos, Berlin, Sterberg Press, 2017, p.153.

71 Idem.

72 Dimendberg, Edward, "Allan Sekula by Edward Dimendberg”, BOMB Magazine, 92 (verano, 2005) [en línea], https://bombmagazine.org/articles/allan-sekula/ [Consulta: 10 de julio de 2020].

73 Carles Guerra, entrevista personal, en Barcelona, 22 de julio de 2019.

74 "The working idea (...) was to move with the flow of protest, from dawn to three a.m. if need be, taking in the lulls, the waiting and the margins of the events. The rule of thumb for this sort of anti-photojournalism: no flash, no telephoto zoom lens, no gas mask, no auto-focus, no press pass and no pressure to grab at all costs the one defining image of dramatic violence". Allan Sekula, citado en Sabine BreITWIESER (ed.), Allan Sekula: performance under working conditions, Generali Foundation, Wien, 2003 , p.310. 
La aproximación a los hechos que pone en práctica Sekula en estas obras plantea una relación diferente con la fotografía al no ocultar su posicionamiento del lado de los protagonistas de las luchas. Si en las series de los ochenta y noventa consiguió reflejar la solidaridad y compañerismo dentro de un entorno laboral concreto (los trabajadores del mar), ahora expande el alcance de los movimientos de protesta a una multitud heterogénea en acción, que abandona sus puestos de trabajo para implicarse en una lucha que afecta a las bases mismas del sistema económico. Sekula pasa a documentar "momentos de asociación" de gran intensidad, ya sea la limpieza del litoral gallego o las protestas en las calles de Seattle contra la élite financiera, evidenciando lo que Benjamin James denomina materialismo solidario o comprensivo ("sympathetic materialism") ${ }^{75}$ una versión más sensible ante la vulnerabilidad humana que la tradicional iconografía del trabajo de tipo marxista. Un buen ejemplo de este acercamiento se puede ver en la película The Lottery of the Sea (2006), donde los momentos intensos se combinan con otros de calma reflexiva.

El mismo año del estreno, Sekula reconocía que The Lottery of the Sea asumía el punto de vista adoptado en Fish Story, ahora comprimido y llevado a formato audiovisual ${ }^{76}$. La película parte del concepto de "juego" tal y como fue usado en su día por Adam Smith en La riqueza de las naciones, aludiendo tanto a la vida de los marineros como al "juego del comercio marítimo", marcados ambos profundamente por el riesgo ${ }^{77}$. Se trata de una película de casi tres horas de duración, segunda incursión del autor en el formato largometraje, donde una voz en off va reflexionando en torno a distintos aspectos del comercio de mercancías en un planeta globalizado ${ }^{78}$.

La película va siguiendo un itinerario aparentemente azaroso por océanos y mares, comenzando en Japón y pasando por Panamá, España, Grecia y Holanda. La parada que realiza en Galicia es especialmente significativa porque sirve de ejemplo de una de las modalidades en las que el riesgo toma forma: se concreta como contaminación, catástrofe que desafía la capacidad de reacción humana. Una feria de millonarios en Ámsterdam muestra la otra cara, la de la riqueza condensada y reunida en pocas manos y, como contrapunto, imágenes de estibadores barceloneses (que aluden a lucha y solidaridad internacional) y las manifestaciones antiglobalización. En cada uno de estos contextos - explica Sekula- el riesgo asume nuevos significados, "es refractado de modo diferente según las circunstancias"

Desastre y riesgo están implícitos en el día a día de los marineros y trabajadores de puertos, señala Sekula, por la posibilidad de sufrir una explosión o un naufragio. El fotógrafo recuerda las palabras de Adam Smith al respecto de los riesgos marítimos: la proporción de naves aseguradas es mayor con respecto a las no aseguradas y es más frecuente esta práctica que en otras actividades ${ }^{80}$. En ocasiones, una compañía o comerciante poderoso aseguran parte de la flota, con la confianza de que, si ocurre alguna desgracia, pueda ser cubierta en parte la pérdida. Pero se minusvalora a menudo el peligro, y todavía cuando Smith escribe es habitual que armadores y mercaderes no hagan uso de esta práctica comercial. Ejemplo del desprecio de los jóvenes por el riesgo: la facilidad con la que se embarcan y se alistan en el ejército, por la confianza en conseguir grandes beneficios ${ }^{81}$.

\footnotetext{
75 JAMES, 2018, p. 128.

76 Conversaciones con fotógrafos. Allan Sekula habla con Carles Guerra, La Fábrica, Madrid, 2006, p.98.

77 "The Lottery of the Sea habla del juego de la vida de los marineros, del juego del comercio marítimo, tal y como lo imaginó Adam Smith y como se juega en la actualidad". Idem.

78 Ibidem, p. 103. "Debía ser una película larga, 'a modo de ensayo', con voz en off y una gama de ámbitos geográficos como los que había explorado en Fish Story".

79 DimendBerg, 2005.

80 Adam SMith, Investigación sobre la naturaleza y causas de la riqueza de las naciones, México D. F., Fondo de Cultura Económica, 1997, p.106.

81 Idem.
} 


\section{Hércules, Sísifo y los estibadores}

Un año antes del desastre del Prestige, en 2001, Sekula había anticipado algunos de sus argumentos en Lisboa, en el marco de una exposición del ciclo Project Room, en el Centro Cultural de Belem, invitado por el coordinador del programa, Jürgen Bock. En la exposición, Sekula presentó una nueva versión de su investigación sobre los trabajos relacionados con el mar, con fotografías que evidenciaban el impacto de la crisis y deslocalización industrial. The Dockers' Museum es un monumento al trabajo de los estibadores, pero exento de grandiosidad, creado -en palabras de Benjamin James- "como una colección de objetos encontrados" $\$ 2$. La instalación se completó con imágenes de la serie Titanic's Wake, ofreciendo otra versión de la crisis del capitalismo a partir de la idea de naufragio. Para Sekula, "la redención postmoderna del tipo pez de la zona portuaria e industrial abandonada de Bilbao, de Frank Ghery, comparte esta arrogancia del naufragio trascendental" $"$.

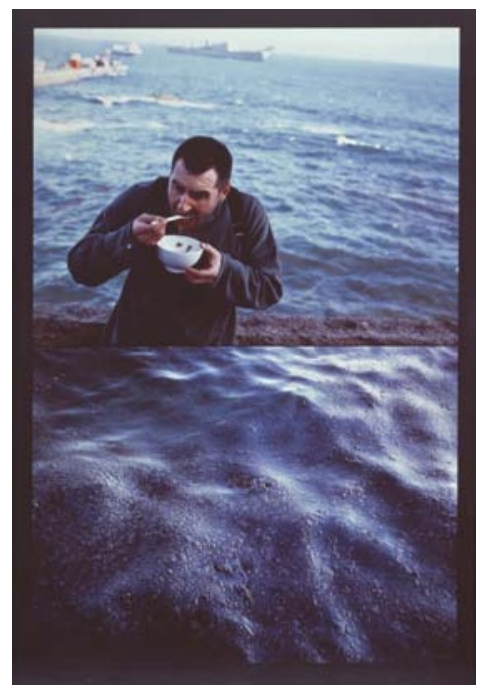

Fig. 13. Allan Sekula, Voluntario comiendo sopa (Isla de Ons, 19/12/02) y Marea negra (Isla de Ons, 19/12/02) de la serie Black Tide/Marea Negra, 2002-2003, cibachrome sobre poliéster, 145,1 x 97 cm, Colección MNCARS, Madrid.

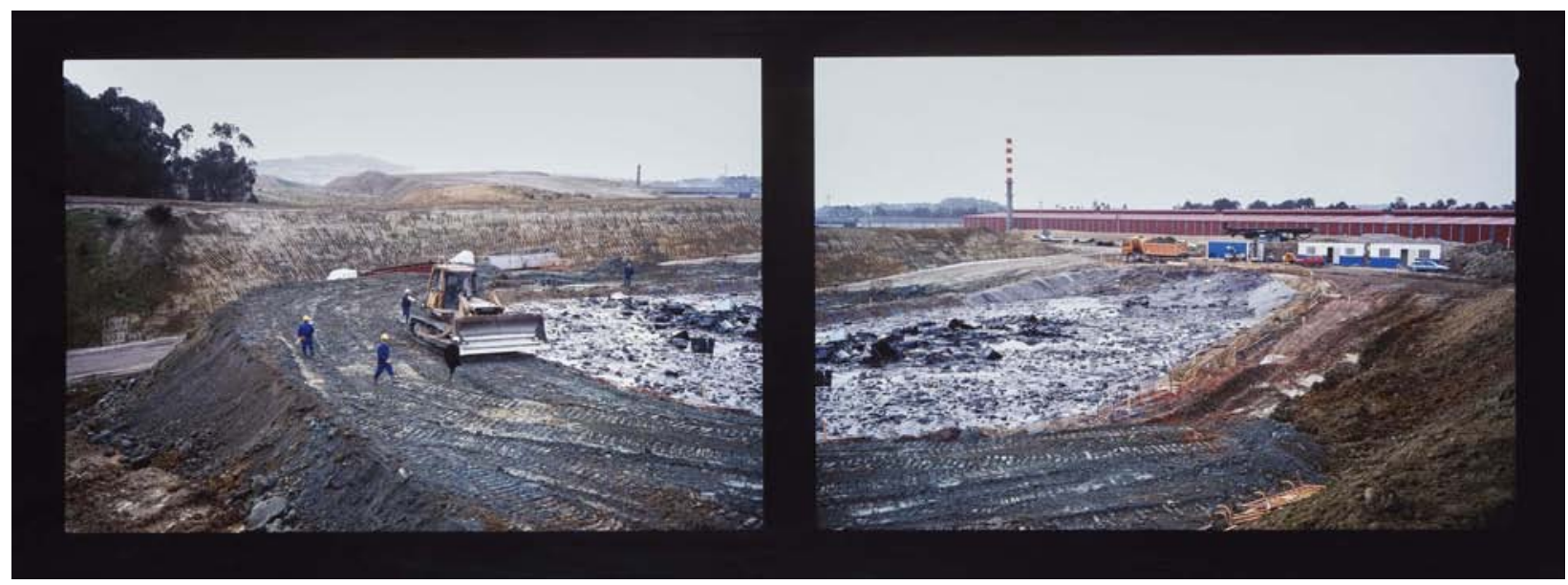

Fig. 14. Allan Sekula, Fosa para desechos [Lendo, 23/12/2002], de la serie Black Tide/Marea Negra, 2002-2003, cibachrome sobre poliéster (díptico), con marco: 54,1 x 127,5 cm, Colección MNCARS, Madrid.

82 JAMES, 2018, p.128.

83 Allan SeKula, “Titanic's wake”, en J. Bock. (ed.), Da obra ao texto. Diálogos sobre a prática e a crítica na arte contemporânea, Lisboa, Centro Cultural de Belem, 2002, p.274. 
La yuxtaposición de temas en la exposición de Lisboa contribuía a la construcción de un relato complejo, un tipo de práctica documental convincente por abordar una historia desde diversos ángulos complementarios. El propósito era -para Sekula- entender el documental fotográfico "como práctica letrada", a partir de la cercanía con otras formas de relato (cinematográfico o novelístico) ${ }^{84}$. El carácter reiterativo, conseguido con la presentación de secuencias, derivará en un diario visual de carácter realista de los dos últimos años del siglo XX. La estrategia discursiva será continuada en Black Tide/Marea negra, con fotos como las del depósito de residuos o las de voluntarios descansando (figs. 13 y 14).

Sekula aludía, en su texto para el catálogo, a unas reflexiones del crítico de cine Manny Farber sobre la dicotomía presente en arte y cine entre gestos grandiosos y gestos menores: "arte de elefante blanco" frente a "arte de termitas" 85 . En el primer caso, películas épicas o melodramáticas; en el segundo, las de carácter intimista o de mayor complejidad argumental. La efectividad y el valor de verdad de este segundo grupo se basaba en el "estar cerca", una inmersión silenciosa en las situaciones. La película Titanic (James Cameron, 1997) sería un buen ejemplo del cine de "elefante blanco", por su apelación a los sentimientos exacerbados, incluso podría ser denominado "de ballena blanca". La figura del trasatlántico podía ser un símil de la crisis o colapso del capitalismo global, de una fase exhibicionista y arrogante, que la superproducción de Hollywood no haría sino prolongar. El hundimiento del Prestige podrá ser visto como un ejemplo de esos momentos de colapso y crisis, de las fragilidades de un sistema basado en la extracción y comercialización de crudo ${ }^{86}$.

La atención de Sekula hacia el trabajo físico en contextos de gran dureza, provocó que en estos años se sirviera de la comparación con figuras de la mitología clásica. El trabajo repetitivo de los voluntarios que limpiaban las costas gallegas le llevó a pensar en el mito de Sísifo a finales del 2002: las manos que retiran, como pueden, el petróleo que llega insistentemente; es el trabajo que nunca se acaba. Y en la Documenta de Kassel de 2007 recurre a Hércules: el trabajador, fuerza de trabajo del capitalismo industrial. En ambos casos, las figuras de la mitología clásica simbolizan el sometimiento a tareas excesivas, inhumanas, peligrosas, donde los dioses imponen a los humanos un castigo y unas pruebas cuya resolución no es previsible, y sitúan a sus protagonistas ante el abismo. Pero a la vez incluyen un elemento disruptivo en la lógica secuencial de Sekula, al introducir el punto de vista épico.

En Kassel Allan Sekula presentó una tercera versión de la obra Shipwreck and Workers, que definiría como un retrato y monumento temporal al trabajo. Se trataba de una instalación de paneles con fotografías impresas, que establecía un diálogo con el teatro de agua del parque de Winterkasten, una instalación estilo rococó conocida por una gran escultura de cobre de Hércules de $1717^{87}$. Sekula propuso repensar y someter a una mirada crítica la tradición del monumento conmemorativo, escultura pública pervertida o "saqueada" a lo largo del siglo $\mathrm{XX}^{88}$. Se mostraban profesiones como herreros y marineros que se complementaban con otras que se añadieron para esta edición de la Documenta: cuidado de niños y sepulture-

84 Ibidem, p. 270.

85 Ibidem, pp. 271-272.

${ }^{86}$ En octubre de 2012 tendría lugar una exposición sobre el desastre del Prestige en relación con las crisis energéticas del capitalismo global, en el Museo de Arte Contemporáneo de Vigo (MARCO). La exposición, que presentaría piezas de Allan Sekula (las fotografias de la serie Marea negra/Black Tide y el vídeo The Lottery of the Sea), fue comisariada por Pedro de Llano y llevaría el título de A balea negra [La ballena negra], en alusión al relato de un sueño del artista ermitaño Manfred Gnädinger (Man, "el Alemán de Camelle"), en el que una enorme ballena muerta se le aparecía, llegando a la Costa da Morte, coincidiendo con el final de los vertidos. En la exposición también se presentó un vídeo de Carles Guerra: Los últimos días de diciembre con Allan Sekula (25 min.), realizada a partir de filmaciones de 2002. http://www.marcovigo.com/content/balea-negra-X-aniversario-do-marco [Consulta: 10 de julio de 2020].

87 Hilde van Gelder, “Allan Sekula. Shipwreck and Workers (Version 3 for Kassel)”, en Documenta 12. Catalogue, Colonia, Taschen (catálogo de la exposición celebrada del 16 de junio al 23 de septiembre de 2007), 2007, p.298. La obra constaba de 26 impresiones en el exterior del Bergpark Wilhemshöhe, en Kassel.

88 Idem. 
ros. En el exterior de la estación de tren se encontraba un panel alargado de grandes dimensiones basado en un poster del movimiento antiglobalización. Es un anuncio -para Hilde van Gelder- del encuentro con lo que Sekula denomina "un Sísifo colectivo no asalariado" 89 .

Dos de los paneles exteriores, de formato vertical, contraponían motivos escultóricos: el de la izquierda dos imágenes de la cabeza del Hércules de bronce diseñado por Johann Jacob Anthoni para Kassel (frente y perfil) y el de la derecha la escultura La mano de Giacometti y El pudelador de Constantin Meunier. Esta fotocomposición alude al mundo del trabajo de modo paradójico y fragmentario, en palabras de Helde van Gelder, se trata de "fragmentos corporales petrificados" 90 . Un poema incorporado de Sekula, titulado "Bring me the head", alude a la figura de Hércules como legado cultural occidental que, significativamente, remite a los trabajos nunca acabados ${ }^{91}$.

Uno de los episodios de The Lottery of the Sea se centra en una categoría profesional que bien podría ilustrar ese carácter entre heroico y trágico de la figura de Hércules: el estibador. En agosto de 2003 Sekula captó en el puerto de Barcelona las imágenes que conforman este episodio92. Ante un escenario "desmesurado" de grandes grúas y contenedores apilados, los estibadores hablan de las amenazas del capitalismo global ("las agresiones ahora son a nivel global") y de la dureza del trabajo. Es un trabajo peligroso, en el que se juegan la vida a diario, entre máquinas y cargamentos de varias toneladas en movimiento constante, que contribuye a forjar un carácter duro que puede llegar a proyectar una imagen negativa de la profesión. Desde fuera parece un gueto, y sin embargo, emerge un sentido de unión y solidaridad entre los estibadores. Como la aldea gala de Asterix y Obelix -se indica en la película- es un reducto que las multinacionales no pueden controlar. Y, desde una dinámica asamblearia, los trabajadores ensayan fórmulas de lucha sindical a escala global, configurando una red internacional que asume que las luchas en este sector ya solo pueden ser eficaces si se realizan de modo coordinado desde geografías distantes.

\section{Conclusiones}

Las dos series realizadas por Sekula en Galicia y los episodios aquí analizados de The Lottery of the Sea evidencian unas pautas características de su modo de trabajo, así como una concepción de la fotografía como herramienta de análisis crítico de la sociedad. Se mantiene en estas piezas, realizadas en sus últimos años de vida, ese impulso dialéctico de su propuesta para una nueva fotografía documental, con la lógica de la secuencia fotográfica, evitando tanto el privilegio de la foto única (el momento culminante), como la imposición de un orden cronológico o lineal. Se combinan momentos de intensidad variada y motivos que van de la figura humana -en reposo o en acción- al escenario de la historia. El recurso a los textos se mantiene (la voz en off hace las funciones de texto escrito en la película), aportando un elemento más para la propuesta de interpretación crítica de la realidad.

La introducción, en estos últimos trabajos, de elementos de marcado carácter simbólico y narrativo no llega a producir una ruptura con respecto a lo anterior, prolonga la concepción dialéctica de su proyecto. Sekula no renuncia a la complejidad en la presentación de materiales, lo que sí se acentúa es una narrativa de tono épico, derivado de la profundidad de las luchas sociales, acercándose así a las dinámicas activas de contestación popular ante los procesos y peligros del capitalismo global. Aún manteniéndose fiel al programa trazado junto a los componentes del grupo de San Diego, Sekula va a evolucionar hacia una

\footnotetext{
89 Idem.

90 GELDER, 2009, p. 224.

91 "Mechanic of the twelve tasks. His work is never done. The Americans give him a thirteenth, unlucky task: Dig the Panama Canal. Use a nuke if you must. Spread democracy". Allan SEKULA, "Bring me the head", citado en Idem.

92 The Lottery of the Sea (2:04:24 en adelante).
} 
narrativa visual donde el elemento dramático gana presencia. Las imágenes captadas en Galicia, en el contexto de la movilización ciudadana por la gestión del accidente del Prestige, fueron de gran importancia para explicar esta evolución, al poner de relieve tanto el acontecimiento traumático como la respuesta colectiva.

Esta acentuación de lo narrativo se produce en Waiting for Tear Gas, Black Tide / Marea Negra, y en The Lottery of the Sea. El carácter simbólico de las figuras y el hecho de tomarlas de la mitología griega acentúan el giro literario en la obra del autor: Sísifo y Hércules funcionan como pasaporte hacia cuestiones trascendentales, de alcance universal, con la tragedia acechando sobre la realidad cotidiana de las personas, pero ahora la lucha se hace patente y alcanza un protagonismo antes no visible en la obra de Sekula. Sea cual sea el resultado de las movilizaciones - parece decirnos el fotógrafo- la mera constatación de que los ciudadanos se unen y plantan cara al poder del capitalismo global es ya de por sí esperanzador.

MIGUEL ANXO RODRÍGUEZ GONZÁLEZ es Profesor de la Universidad de Santiago de Compostela (USC), está especializado en Arte Contemporáneo y Teoría del Arte. Participa desde 1998 en proyectos de investigación sobre escultura contemporánea, paisaje urbano e industria cultural, realizando estancias de investigación en s-Hertogenbosch (Holanda) y Winchester (Reino Unido). Su trabajo de investigación se enmarca en la Historia social del arte en la segunda mitad del siglo XX, con estudios sobre escultura contemporánea, formación artística, y sobre relaciones entre arte, ideología y políticas culturales.

Ha colaborado en diversas actividades del Centro Galego de Arte Contemporánea, desde la realización de jornadas y conferencias a la elaboración de textos para catálogos. Ha publicado en revistas académicas de las universidades de Granada, Autónoma de Madrid, Universitat de Barcelona y UNED, entre otras. Fue coordinador hasta 2011 del máster Arte, Museología y Crítica Contemporáneos, de la USC, y director en 2009 del curso de verano "La espectacularización de la cultura" (Santiago de Compostela). Fue coordinador del volumen Canales alternativos de creación. Una aproximación histórica (Compostela, 2013) y del seminario "Nuevas narrativas en la historia del arte contemporánea" (CGAC, Compostela, 2017).

Email: Miguelanxo.rodriguez@usc.es

Código ORCID: https://orcid.org/0000-0002-8926-1762 